\title{
EXPLOITATION OF SOLAR ENERGY COLLECTED BY THE PLASTIC GREENHOUSES FOR DRYING AGRICULTURAL AND INDUSTRIAL WASTES OF BANANA
}

Said Elshahat Abdallah* Wael Mohamed Elmessery** Aly Badawy Elnaggar*** Asmaa Gamal Eldreeny****

\section{ABSTRACT}

Banana is the most waste generation among economic plants in the field due to sequence operations done during production year around. Drying air characteristics; greenhouse solar drier effectiveness; banana tree residues and banana peels distribution way on drying trays are highlighted for drying process optimization. Dried banana wastes introduced for lamb feeding is investigated. Both energy and exergy analyses of the drying process of banana wastes, using three different solar collectors in geometric shape with three independent drying chambers having the same geometric dimensions (mixed-mode forced convection type solar drier), are presented. Banana wastes get sufficiently dried at temperatures between $30^{\circ} \mathrm{C}$ and $54^{\circ} \mathrm{C}$. Throughout the experimental procedure, air relative humidity did not exceed $66 \%$, and solar radiation ranged from 69.34 to $871.6 \mathrm{~W} / \mathrm{m}^{2}$. Drying air mass flow was maintained within the interval of 0.0130 to $0.0143 \mathrm{~kg} / \mathrm{s}$. Under these experimental conditions, two days were needed to reduce the moisture content to approximately one-fifteenth of the original value, in particular from $14.153 \mathrm{kgH}_{2} \mathrm{O} / \mathrm{kg}$ dry matter down to $0.9 \mathrm{kgH}_{2} \mathrm{O} / \mathrm{kg}$ dry matter via Cylindrical solar drier. The Cylindrical solar collector has the highest effect on the drying air capacity which can increase it rapidly decreasing moisture content dramatically in the second day, with the highest drying rate of $0.0302 \mathrm{~kg} \mathrm{H}_{2} \mathrm{O}$ and drying efficiency of $46.2 \%$ for

KEYWORDS: Solar drying process evaluation, banana wastes, thermodynamics analysis.

\footnotetext{
* Associate Prof., Ag. Eng. Dept., Fac. of Ag., Kafrelsheikh Univ., Egypt. ** Lecturer, Ag. Eng. Dept., Fac. of Ag., Kafrelsheikh Univ., Egypt. *** Researcher, Agricultural Engineering Research Institute, Egypt. *****M.Sc. Student, Ag. Eng. Dept., Kafrelsheikh Univ., Egypt.
} 
banana wastes with bed depth of $5 \mathrm{~cm}$ and chopping length of $3 \mathrm{~cm}$ and $32.5 \%$ for banana peels with bed depth of $5 \mathrm{~cm}$. Energy utilization ratio for Cylindrical, Quonset and Trapezoidal solar driers is 48.77, 52.06 and $55.58 \%$ respectively. The product with chopping length of $3 \mathrm{~cm}$ has the highest pick-up efficiency with both bed depths of 5 and $8 \mathrm{~cm}$ due to its higher specific surface area. Multiple linear regression analysis was done for studying the regress variables of wastes bed depth, chopping length, specific enthalpy of drying air, drying air capacity, heat energy gained, exergy and moisture content with drying rate and multiple linear regression equations are developed. Implementation of the first law of thermodynamics, energy analysis was carried out to estimate the amounts of heat energy gained from the created solar collectors and the ratio of energy utilization of the drying chamber. Also, applying the second law, exergy analysis was developed to determine the type and magnitude of exergy needed during the solar drying process. It was found that the great amount of exergy losses have been mainly taken place during the second drying day, when the available energy was less used. The summation of exergy required was of 0.36, 0.1423 and 1.5 $\mathrm{kJ} / \mathrm{kg}$ for the Cylindrical, Quonset and Trapezoidal solar driers during the first drying day, and of 0.94186, 0.44184 and $1.218 \mathrm{~kJ} / \mathrm{kg}$ respectively during the second drying day.

\section{NOMENCLATURE}

$\begin{array}{ll}\mathrm{M}_{\mathrm{o}} & \text { Initial moisture content, } \mathrm{kg} \mathrm{kg}^{-1} \mathrm{~d} . \mathrm{b} . \\ \mathrm{M}_{\mathrm{t}} & \text { Moisture content at time } \mathrm{t}, \mathrm{kg} \mathrm{kg}-1 \mathrm{~d} . \mathrm{b} . \\ \mathrm{W}_{\mathrm{o}} & \text { Initial weight of the dried product, } \mathrm{kg} \\ \mathrm{W}_{\mathrm{t}} & \text { Weight of product to be dried at any time, } \mathrm{kg} \\ M_{W} & \text { Mass of evaporated water from the product, } \mathrm{kg} \text { at time } \mathrm{t} \\ M d s & \text { Mass of dry solids, } \mathrm{kg} \\ T & \text { Time of drying, } \mathrm{s} \\ \eta_{\mathrm{d}} & \text { System drying efficiency, } \% \\ \Delta H l & \text { Latent heat of water evaporation, } \mathrm{kJ} \mathrm{kg}^{-1} \\ I & \text { Solar radiation incident on the aperture surface, } \mathrm{W} \mathrm{m}^{-2} \\ A & \text { Aperture area of the drier, } \mathrm{m}^{2} \\ P f & \text { Energy consumption of fan, } \mathrm{kW} . \mathrm{h} \\ M_{W 1} & \text { Mass of evaporated water from the product during the first drying } \\ & \text { day, } \mathrm{kg}\end{array}$


$\begin{array}{ll}\eta_{c} & \text { Heat collection efficiency, unit } \\ Q_{u} & \text { Useful energy gain rate, } \mathrm{W} \\ A_{c} & \text { Energy collection area of solar collector, } \mathrm{m}^{2} \\ C_{P} & \text { Specific heat at constant pressure, } \mathrm{kJ} / \mathrm{kg} . \mathrm{K} \\ \dot{m}_{a} & \text { Mass airflow rate, } \mathrm{kg} \mathrm{s}^{-1} \\ T_{i} & \text { Inlet temperature of drying air, }{ }^{\circ} \mathrm{C} \\ T_{o} & \text { Outlet temperature of drying air, }{ }^{\circ} \mathrm{C} \\ h_{o} & \text { Absolute humidity of air leaving the drying chamber, } \mathrm{kg} \mathrm{H}_{2} \mathrm{O} / \mathrm{kg} \text { dry }\end{array}$

$h_{i} \quad$ Absolute humidity of air entering the drying chamber, $\mathrm{kg} \mathrm{H}_{2} \mathrm{O} / \mathrm{kg}$ dry air

$h_{\text {as }} \quad$ Drying air absolute humidity at the point of adiabatic saturation, $\mathrm{kg}$ $\mathrm{H}_{2} \mathrm{O} / \mathrm{kg}$ dry air

$h_{\text {ref }} \quad$ Reference absolute humidity (instantaneous state)

$T_{\text {as }} \quad$ Drying air temperature at the point of adiabatic saturation, ${ }^{\circ} \mathrm{C}$

$\eta_{p} \quad$ Pick-up efficiency, $\%$

$\rho \quad$ Density of air, $\mathrm{kg} \mathrm{m}^{-3}$

$V_{t} \quad$ Volumetric airflow rate, $\mathrm{m}^{3} \mathrm{~s}^{-1}$.

$A_{t} \quad$ Total aperture area of the drier, $\mathrm{m}^{2}$

$h_{L} \quad$ Latent heat of vaporization, $\mathrm{kJ} / \mathrm{kg} .{ }^{\circ} \mathrm{C}$

$s e_{d r, i}$ Specific enthalpy of drying air at drying chamber inlet, $\mathrm{kJ} / \mathrm{kg}$

$s e_{d r . o}$ Specific enthalpy of drying air at drying chamber outlet, $\mathrm{kJ} / \mathrm{kg}$

$T_{c . o} \quad$ Air temperature at solar collector outlet, ${ }^{\circ} \mathrm{C}$

$T_{c . i} \quad$ Air temperature at solar collector inlet, ${ }^{\circ} \mathrm{C}$

EUR Energy utilization ratio, \%

D5 Banana residues bed depth of $5 \mathrm{~cm}$

D8 Banana residues bed depth of $8 \mathrm{~cm}$

T3 Banana residues chopping length of $3 \mathrm{~cm}$

T5 Banana residues chopping length of $5 \mathrm{~cm}$

$\mathrm{P} \quad$ Banana peels

$\mathrm{AC}_{\mathrm{H}} \quad$ Drying air capacity based on absolute humidity

$\mathrm{AC}_{\mathrm{T}} \quad$ Drying air capacity based on temperature 


\section{INTRODUCTION}

nimal feed resources are limited and do not allow animal
production to increase that meeting human consumption of
protein. Forages are also unevenly divided between summer and winter. The major problem appears in summer season where there is no more alternative animal feed of clover. Due to forages shortage in Egypt, nutritionists thought about the nutritive values of crop residues and agroindustrial by-products and the possibility of using them for animals feeding as it is, or after improving its nutritive values physically, chemically, or biologically. Banana leaves and pseudostems have chemical analysis close to clover and can play an important role to cover some nutrient requirements of the animals (Abd El-Gawad et al., 1994). Highest live weight was achieved when diet was supplemented with banana (Ibrahim et al., 2000). In addition, the banana wastes are available year around. The overall cultivated area of banana farms in Egypt is 64297.5 feddan. Egypt is considered to be the third country in banana production after Nigeria and Australia; banana wastes are 40 tones per feddan for a year (Ministry of Agriculture, 2013). Drying process is considered to be a preliminary treatment for further processes conducted on the industrial agro-based wastes and crop residues to feed cattle and goats, such as sugar beet tops (Abdallah, 2010). (Mohapatra et $\boldsymbol{a l}$., 2010) reported the nutritive value of banana foliage. Numerous research works relating the mathematical modeling and the kinetics of the drying process of vegetables, fruits and agro-based products are available at present in the scientific literature, such as those concerning pistachio (Midilli and Kukuk, 2003a), green beans (Doymaz, 2005a), okra (Doymaz, 2005b), carrots (Doymaz, 2004), bananas (Karim and Hawlader, 2005), potatoes and apples (Akpinar, 2005), red peppers (Akpinar et al., 2003), figs (Babalis and Belessiotis, 2004), mint leaves (Doymaz, 2006), eggplants (Ertekin and Yaldiz, 2004), green peas (Simal et al., 1996), black tea (Panchariya et al., 2002) and prunes (Sabarez and Price, 1999). Thermal drying in solids might be regarded as the result of two simultaneous actions: a heat transfer process by which the moisture content of the solid is reduced, and a mass transfer process that implies fluid displacement within the structure of the solid 
towards its surface. Such motion is reported to depend on the structure, the moisture content and some other specific features of the material. Also, the separation of vapor from the solid substrate depends on the external pressure and temperature, on the total area of the solid surface, on Reynolds number and on the moisture content of drying air. Provided that thermal drying takes place very slowly at ambient conditions, drying plants are devoted to accelerate the process in order to achieve appropriate drying rates or, in other words, to supply the product with more heat than is available under ambient conditions (Dincer and Sahin, 2004). The drying airflow can be obtained by natural or forced convection. (Ekechukwa and Norton, 1999) reported a detailed analysis of a large number of active and passive solar drying plants, focusing on their viability in rural areas. In the recent past, considerable efforts have been made to design and develop several types of solar driers around the globe (Leon et al., 2002 and Singh et al., 2004). Properly designed solar driers may prove to be energy saving devices for drying process (Hossain et al., 2005 and Zhiqiang, 2005). Out of the various solar drier designs developed and tested, the performance of mixed-mode driers is found to be the most effective in terms of product drying rate and drying cost (Simate, 2003). Furthermore, these driers incorporate the benefits of combined action of solar radiation incident directly on the food product to be dried and preheated air from solar collector connected to the drying chamber. Energy and exergy analysis for crop residues and agroindustrial materials drying was studied by (Celma and Cuadros, 2009 and Ceylan and Ergun, 2014). (Amer et al., 2010) designed and evaluated the performance of hybrid solar drier for banana. The drier consists of solar collector, reflector, heat exchanger cum heat storage unit and drying chamber. The drying chamber was located under the collector. The drier was operated during normal sunny days as a solar drier, and during cloudy day as a hybrid solar drier. One of the main goals in the design and optimization of industrial drying processes is to use as less energy as possible for maximum moisture removal for the desired final conditions of the product. As a consequence, energy quantity and quality as well as heat and mass transfer should be investigated throughout the drying process (Akpinar et al., 2006). 
Therefore, a rigorous analysis of the convective drying process should be based on the mass and energy conservation principles as well as on the exergetic balance of the process, i.e. on the first and second laws of thermodynamics (Celma and Cuadros, 2009). The exergy of a thermodynamic system is defined as the maximum theoretical useful work (shaft work or electrical work) that can be obtained until thermodynamic equilibrium with the environment is reached, in presence of no other interacting system (Tsatsaronis, 2007). In order to achieve an efficient use of energy resources, exergy losses should be reduced as much as possible in all physical processes. In this sense, the exergetic analysis is required to locate and characterize the causes of exergy destruction or exergy loss, as well as to quantify the corresponding rates. Therefore the essential aim of the current investigation is to exploit the collected solar energy by different plastic greenhouses to be utilized for drying the agro-industrial wastes of banana. The specific objectives are to study the influence of different chopping lengths and drying bed depths of banana wastes on its drying rate; to determine the best geometrical shape of greenhouse solar collectors which ensure the highest thermal use efficiency for achieving drying experiments and to analyze both of the energy and exergy during solar drying process.

\section{MATERIALS AND METHODS}

Limited information about the energy and exergy analyses of banana residues (Peels, leaves and sheathes, pseudostem, pith and male bud) using solar drying process is available in the scientific websites literatures. Provided the high solar radiation levels in the middle regions of Egypt, and in particular in Elnobariah city, Elbeheirah governorate (where most of the banana farms are located 20113 feddan). Works on design and constructing suitable solar drier for banana residues and industrial by-products lead to an improvement of environmental management as having great interest. Note, for instance, that the total amount of banana residues per feddan reaches an approximate value of $2.5719 \times 10^{6}$ tons per year in virtue $154 \%$ of banana production (Ministry of Agriculture, 2013). The present research work is intended to provide a possible solution to the above-mentioned problem. To do so, prototype solar drying plant has been manufactured, constructed, 
installed, and a series of experiments have been carried out in order to achieve relevant data on the energy and exergy analyses of solar drying process. The effect of thermal treatment on nutrition value of the dried product was also investigated. Lambs low growth rates are recorded, which the low intake of digestible dry matter, the recommended dry matter for banana residues is $101 \mathrm{~g}$ dry matter/kg foliage (MarieMagdeleine et al., 2010).

\section{EXPERIMENTAL SETUP}

The experimental setup, shown in Figure 1, consisted of three different forms of greenhouse solar collector and a greenhouse drying chamber, Figure 2. A centrifugal suction fan was mounted at tray beneath to circulate the drying air inside the drying chamber and force it to penetrate the crop residues. A solar radiation sensor, Model (H-201) was connected to a chart recorder Model (YEW 3057) to convert the voltage signal to an equivalent reading in $\mathrm{kWh} / \mathrm{m}^{2}$. The solar radiation was measured and recorded during the period started from 10:00AM to 6:00PM. The available solar radiation was determined every hour by using the equation of $S E=S R \times A_{g}$; where $S E$ is available solar energy, kWh; $S R$ is solar radiation flux incident on greenhouse surface, $\mathrm{kW} \cdot \mathrm{h} / \mathrm{m}^{2}$, and $A_{g}$ is the greenhouse area, $\mathrm{m}^{2}$. Three thermocouples were used to measure the heated air temperatures inside the solar collectors aligned vertically with equal distances, Figure 3; other thermocouples were located centrally inside the drying chamber and the last one at fan outlet. The thermocouples were connected with electronic data logger, LOGBOX-AAIP65 and its wireless interface with USB cable to record the temperature readings every hour intervals. The thermocouples used were K-type with accuracy of $\pm 0.1^{\circ} \mathrm{C}$. A hot wire anemometer, model Kanomax 24-6111, was used to measure the outlet air velocity of fan in $\mathrm{m} / \mathrm{s}$. Air temperature and relative humidity for the ambient and heated air were measured by a digital temperature and humidity meter, Model Chino HNK. The measurements were done at hour intervals. Samples of banana residues were gathered from different positions of each drier every hour interval. The banana residues moisture content was measured by an oven set at $60^{\circ} \mathrm{C}$ for $48 \mathrm{~h}$ as recommended by (ASAE, 1998). 


\section{EXPERIMENTAL PROCEDURE}

This study was carried out at Rice Mechanization Center in Meet Eldeebah village in cooperation with Animal Production Research Station in Sakha village, Kafr Elsheikh governorate, Egypt. Drying experiments were conducted during August 2013, with maximum and minimum air temperatures around 38 and $23^{\circ} \mathrm{C}$, respectively. Air relative humidity did not exceed $66 \%$ and solar radiation ranged between 69.34 and $871.6 \mathrm{~W} / \mathrm{m}^{2}$. Banana residues were chopped mechanically with definite lengths of 3 and $5 \mathrm{~cm}$ (T3 and T5) but the peels were left as they are. Samples were spread on the tray with bed depths of 5 and $8 \mathrm{~cm}$ (D5 and D8). Drying experiments were performed with six trays for each trial inside greenhouse solar drier. During solar drying process, the drying air temperature depends on the value of the incident solar radiation. In all experiments described here, no additional heating energy was supplied to the samples apart from direct solar radiation. The circulation fan was used in this work with air velocity of $1.5 \mathrm{~m} / \mathrm{s}$. The experiments ended when the moisture content of the samples were reduced from $14.153 \mathrm{~kg}$ $\mathrm{H}_{2} \mathrm{O} / \mathrm{kg}$ dry matter to a final value of approximately $0.9 \mathrm{~kg} \mathrm{H}_{2} \mathrm{O} / \mathrm{kg}$ dry matter. To do so, the load/unload cycle was set from 10:00AM first drying day until 6:00PM second drying day. Moisture loss, ambient temperature and relative humidity, inlet and outlet temperatures of drying air in the greenhouse solar collector and drying chamber were recorded at 60min intervals during the drying process.

\section{DRYING AIR CHARACTERISTICS}

\section{Drying air capacity}

The capacity of air for moisture removal depends on its humidity and its temperature. Drying air capacity is an important indicator determining the drying air power; two terms are used to declare the amount of drying force or moisture tension based on absolute humidity difference and on air temperature difference. The drying air capacity based on absolute humidity is defined as the difference between air absolute humidity and the absolute humidity at adiabatic saturation or the difference between dry temperature and air temperature at adiabatic saturation (thermodynamic wet-bulb temperature). 


$$
\begin{aligned}
& A C_{H}=h_{\text {ref }}-h_{\text {as }} \\
& A C_{T}=T_{\text {ref }}-T_{a s}
\end{aligned}
$$

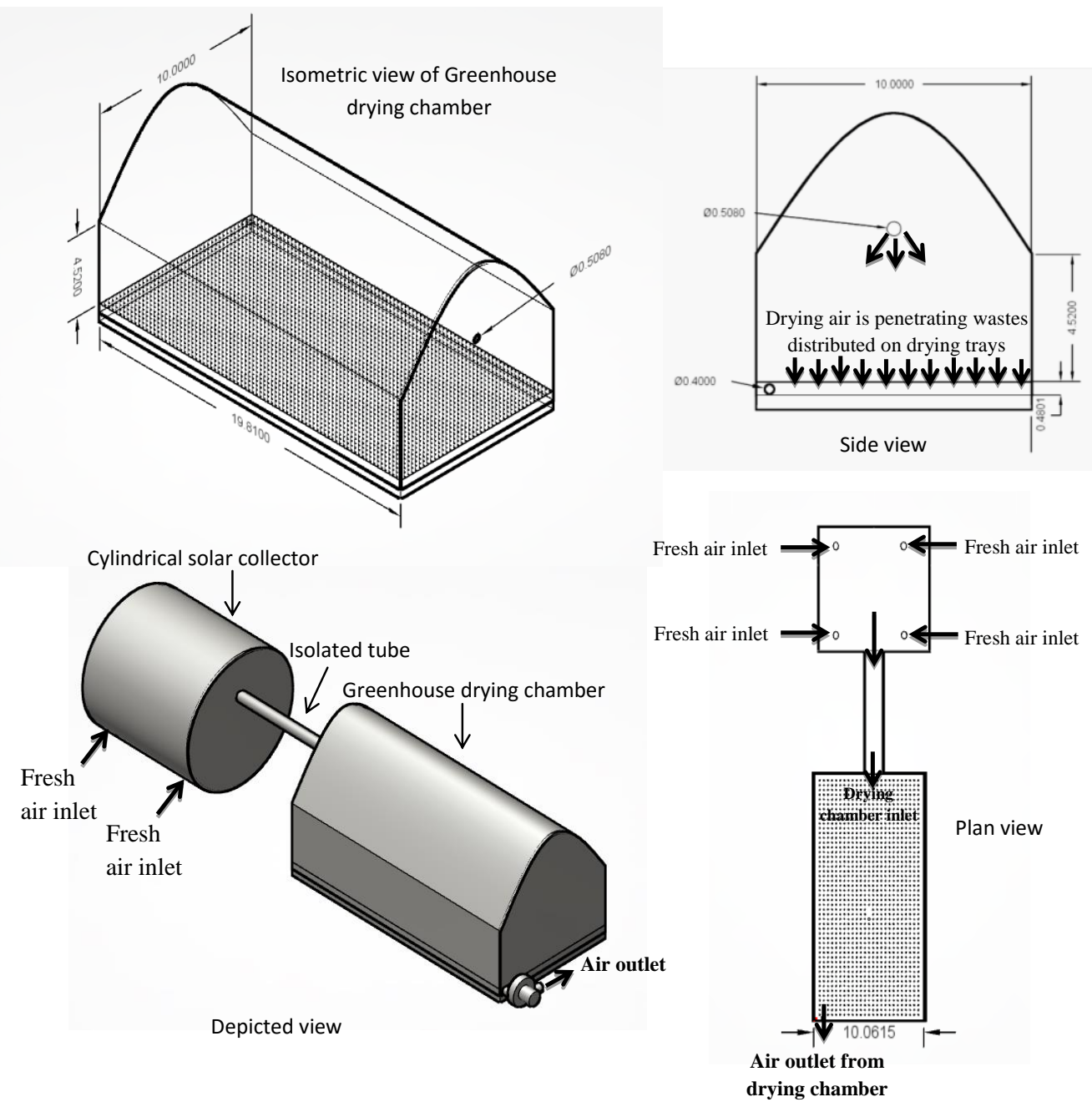

Eqn 2

Figure 1: Greenhouse Cylindrical solar drier consisted of Cylindrical solar collector and greenhouse drying chamber.

\section{Specific enthalpy}

Corresponding to the specific heat (cp) of gases is the humid heat (cs) of moist air. It is used in the same way as a specific heat; the enthalpy change being the mass of dry air multiplied by the temperature difference is called sensible enthalpy and by the humid heat also called latent enthalpy. The units are $\mathrm{kJ} / \mathrm{kg} .{ }^{\circ} \mathrm{C}$ and the numerical values can be read off a psychrometric chart. 
Trapezoidal solar collector

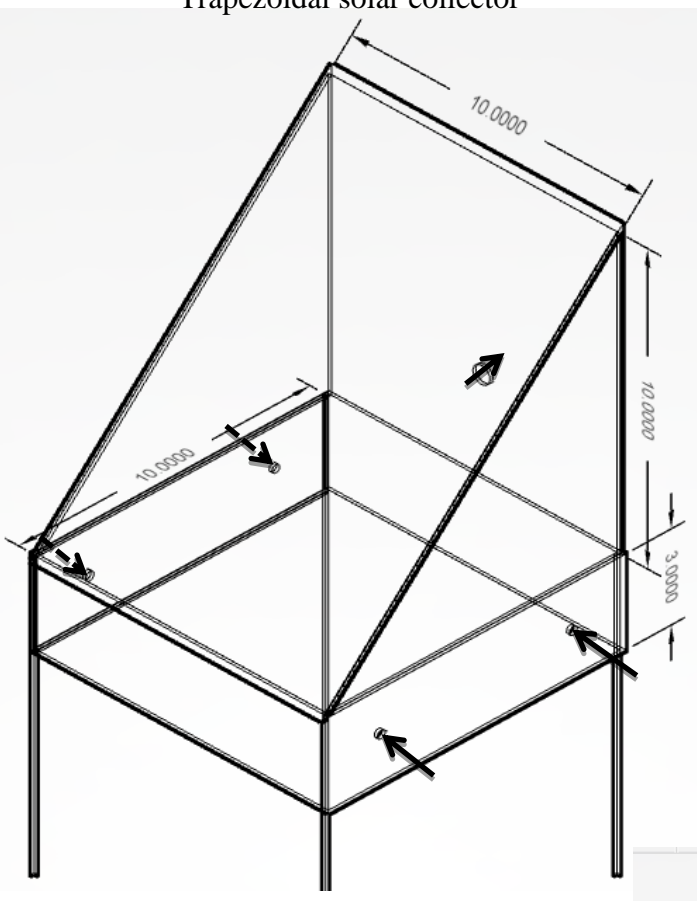

Cylindrical solar collector

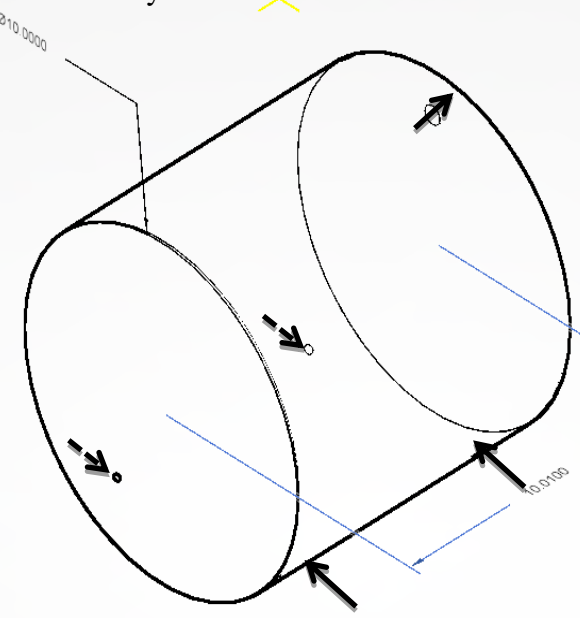

Dimensions In $\mathrm{Cm}$.

Scale

$1: 10$

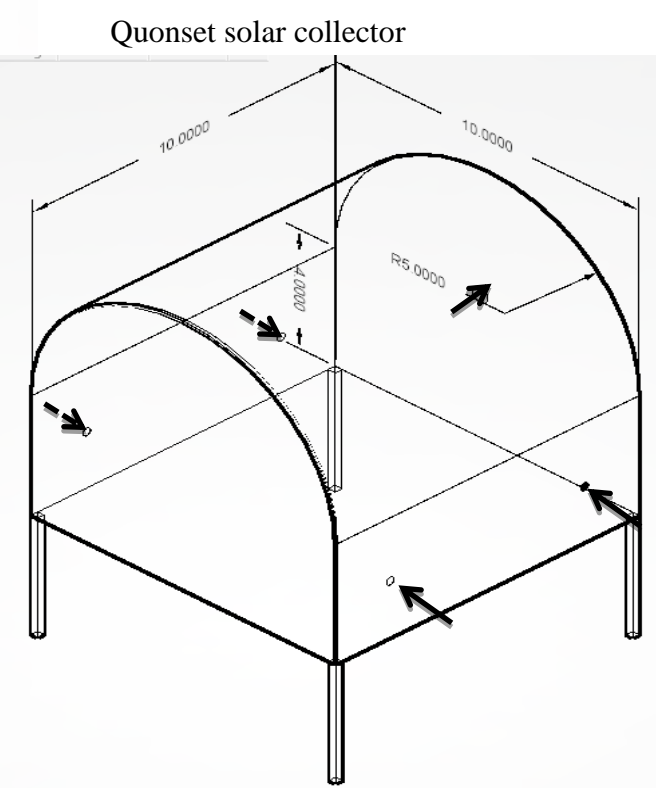

Figure 2: Three different greenhouse solar collector arrows show air directions solar of collector inlets and outlet. 


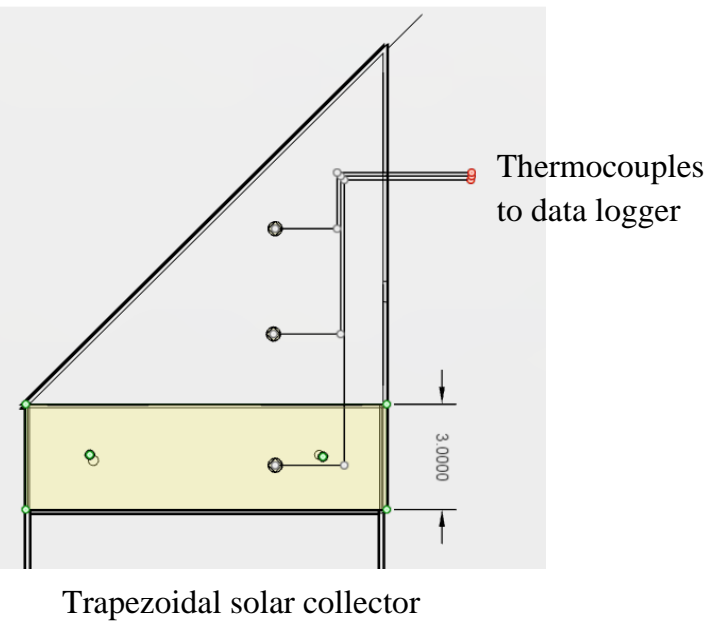

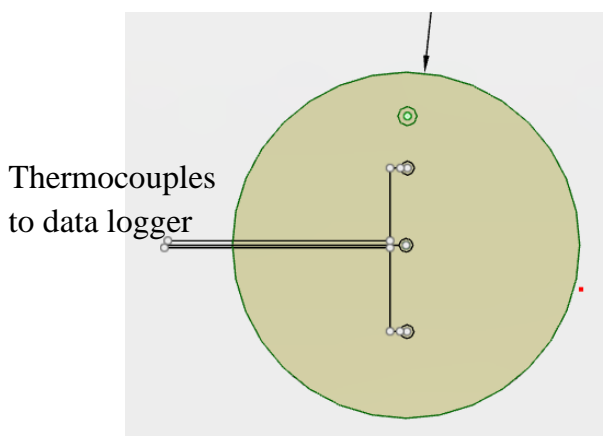

Cylindrical solar collector

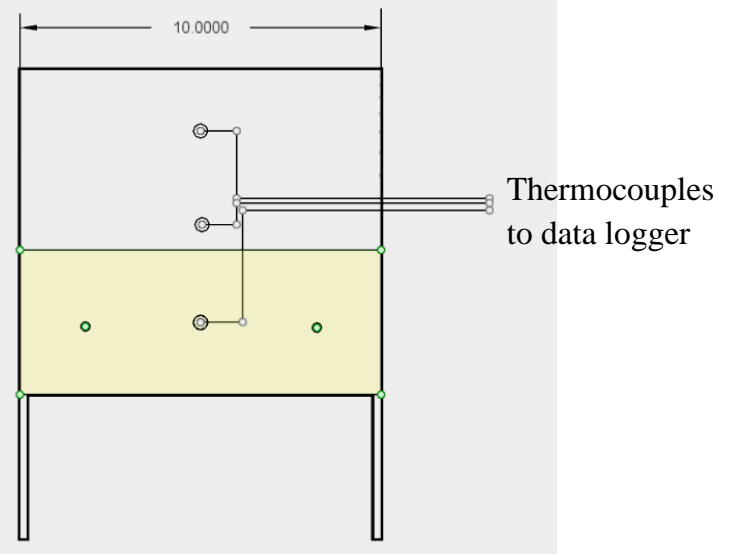

Quonset solar collector

Figure 3: Thermocouples positions inside the three greenhouse solar collectors.

It differs from specific heat at constant pressure in that it is based only on the mass of the dry air. The specific heat of the water it contains is effectively incorporated into the humid heat which therefore is numerically a little larger than the specific heat to allow for this. Change in enthalpy of air is equal to heat transferred convectively to the product and heat supplied to air in the evaporated moisture (Hossain et al., 2005). 


\section{GREENHOUSE SOLAR DRIER PERFORMANCE}

\section{Energy analysis}

An energy analysis of the thick-layer drying process was performed to better determine the energetic aspects as well as the behavior of the drying air throughout the forced convection type solar drier. During drying process, air conditioning includes heating, cooling and humidification (Midilli and Kucuk, 2003a), and such steps can be modeled as steady flow processes to be analyzed by using the principles of steady flow conservation of mass (for dry air and moisture) and energy. The general equation of mass conservation of drying air can be expressed as

$$
\sum\left(\dot{m}_{s h i}+\dot{m}_{m p}\right)=\sum \dot{m}_{s h o} \text { or } \sum\left(\dot{m}_{d a i} s h_{i}+\dot{m}_{m p}\right)=\sum \dot{m}_{d a i} s_{o}
$$

Eqn 3

$\dot{\boldsymbol{m}}_{\boldsymbol{s h i}}$ and $\dot{\boldsymbol{m}}_{\boldsymbol{s h} \boldsymbol{o}}$ being the inlet and the outlet mass flows of specific humidity, respectively; $\dot{\boldsymbol{m}}_{\boldsymbol{m p}}$ is the mass flow of moisture of the product; $\boldsymbol{s} \boldsymbol{h}_{\boldsymbol{i}}$ is the inflow specific humidity and $\boldsymbol{s} \boldsymbol{h}_{\boldsymbol{o}}$ is the outflow specific humidity. Finally, the general equation of energy conservation has the form:

$$
\dot{Q}-\dot{W}=\sum \dot{m}_{d a o}\left(e_{d a o}+\frac{v_{d a o}^{2}}{2}\right)-\sum \dot{m}_{d a i}\left(h_{d a i}+\frac{v_{d a o}^{2}}{2}\right)
$$

Eqn 4

Where e is the enthalpy, $\dot{\boldsymbol{v}}$ is the velocity of the drying air, $\dot{\boldsymbol{Q}}$ is the net heat rate and $\dot{\boldsymbol{W}}$ is the energy utilization rate. In general, drying processes depend on the changes produced in the properties of the drying air - wet air in our case. Therefore, values of the main psychrometric variables need to be determined in order to analyze air's features during the drying process. For this purpose, wet air will be considered as a one-phase homogeneous system with two components that is governed by the ideal gas laws for fluid mixtures. On-line psychrometric chart program (Psychrometrics, 2013) used 
for determining of the psychrometric and thermodynamic properties is based on the consideration of $10.2 \mathrm{~m}$ altitude above sea level and the results are within the scope of ANSI/ASHRAE 41.6-1994. The absolute humidity and temperature at adiabatic saturation were also determined by the program of Psychrometric Chart + Duct Calculator V4.4; the program uses IAPWS-IF97 equation for water/vapor properties calculating, and treats moist air as real gas for high precision.

\section{Determination of the outlet conditions of greenhouse solar collectors}

The inlet conditions of the solar collector were assumed as being equal to the ambient conditions:

$s h_{c i}=s h_{a m b} ; T_{c i}=T_{a m b} ; r h_{c i}=r h_{a m b} ; s e_{c i}=s e_{a m b} \quad$ Eqn 5

Where subscript $c i$ defines the collector inlet and $a m b$ the ambient. Using the values of the outlet and inlet temperatures of the solar collector, the useful energy gain by the drying air, $\dot{Q}_{u d a}$, was determined from equation 6:

$$
\dot{Q}_{u d a}=\dot{m}_{d a} C_{p d a}\left(T_{c o}-T_{c i}\right)
$$

Where $T_{c i}$ and $T_{c o}$ refer to the drying air temperatures at the inlet and outlet of the solar collector, respectively. Provided that the psychrometric transformation of wet air inside the collector is exclusively a sensible heating, we have that $s h_{c o}=s h_{c i}$, and therefore the values of relative humidity $\left(r h_{c o}\right)$ and specific enthalpy $\left(s e_{c o}\right)$ at the outlet of the air solar collector can be fitted using the psychrometric program.

\section{Determination of the inlet and outlet conditions of greenhouse drying chamber}

The setup of the solar drier was assumed to be such that the conditions of drying air at the inlet of the drying chamber were the same as those at the outlet of the solar air heater. This way, the small heat losses that may develop between the heater outlet and the drying chamber inlet are neglected, and hence one has where subscript $d c i$ defines the drying chamber inlet and ho the heater outlet. 
$s h_{d c i}=s h_{c o} ; T_{d c i}=T_{h o} ; r h_{d c i}=r h_{h o} ; s e_{d c i}=s e_{h o} \quad$ Eqn 7

Using Eqn 3, the values of the specific humidity of the drying air at the outlet of the drying chamber can be calculated as follows:

$$
s h_{d c o}=s h_{d c i}+\frac{\dot{m}_{w p}}{\dot{m}_{d a}}
$$

Where $s h_{d c i}$ denotes the specific humidity of the drying air at the inlet of the drying chamber and $\dot{m}_{w p}$ is the mass flow rate of the moisture removed from the residues on the tray. The relative humidity and the enthalpy of the drying air at the outlet of the drying chamber were estimated using the psychrometric chart program. During the drying process at the tray inside the drying chamber, the heat used can be calculated by using the psychrometric chart together with the following equation:

$$
\dot{Q}_{d c}=\dot{m}_{d a}\left(s e_{d c i}-s e_{d c o}\right)
$$

\section{Exergy analysis}

Thermodynamic analysis, particularly exergy analysis, has appeared to be an essential tool for system design, analysis and optimization of thermal systems, including drying systems (Dincer and Sahin, 2004). Exergy is defined as the maximum amount of work which can be produced by a stream of matter, heat or work as it comes to equilibrium with a reference environment. In the drying industry, the goal is to use a minimum amount of energy for maximum moisture removal for the desired final conditions of the product. Several studies have been conducted on exergy analysis of food drying (Dincer, 2002). Exergy is a measurement of the maximum useful work that can be done by a system interacting with an environment at a constant pressure and temperature. The simplest is that of a reservoir with heat source of infinite capacity and invariable temperature. The maximum efficiency of heat withdrawal from a reservoir that can be converted into work is called the Carnot efficiency (Tsatsaronis, 2007). The features of exergy are identified to highlight its importance in a wide range of applications (Midilli and Kucuk, 2003b ). Exergy analysis has been increasingly as a useful tool 
in the design, assessment, optimization and improvement of energy systems (Doymaz, 2005). The exergy was determined based on the following equation:

$$
\text { Exergy }=\dot{m} C_{P}\left[\left(T-T_{\text {ref }}\right)-T_{\text {ref }} \ln \frac{T}{T_{\text {ref }}}\right]
$$

\section{Energy utilization ratio}

The energy utilization ratio of the drying chamber $\left(E U R_{d c}\right)$ is defined as the ratio of the energy utilization for drying to the useful solar energy and is generally calculated by using the following equation using the psychrometric chart:

$$
E U R=\frac{\dot{m}\left(s e_{d r . i}-s e_{d r . o}\right)}{\dot{m} C_{P}\left(T_{c . o}-T_{c . i}\right)}
$$

Where $\dot{m}$ the mass flow rate $(\mathrm{kg} / \mathrm{s})$, se the specific enthalpy $(\mathrm{kJ} / \mathrm{kg}), C_{p}$ the specific thermal capacity of air $(\mathrm{kJ} / \mathrm{kg} \mathrm{K})$, $\mathrm{T}$ temperature $\left(\mathrm{K}\right.$ or $\left.{ }^{\circ} \mathrm{C}\right)$.

\section{Thermal efficiency of solar collector and drying chamber}

A measure of solar collector performance is the collector efficiency or heat collection efficiency, defined as the ratio of useful heat gain over any time period to the incident solar radiation over the same period (Koyuncu, 2006), thus collection efficiency can be defined as:

$$
\eta_{c}=Q_{u} / A_{\text {I. }}
$$

The useful heat gain by a solar collector can be expressed as:

$$
Q_{u}=\dot{m}_{a} . C_{P a}\left(T_{o}-T_{i}\right)
$$

From Eqns 12 and 13,

$$
\eta_{c}=\dot{m}_{a \cdot} C_{P a}\left(T_{o}-T_{i}\right) /_{I . A_{c}}
$$

Eqn 14

\section{DRYING PROCESS PERFORMANCE ANALYSIS}

\section{Instantaneous moisture content (Mt)}

To evaluate the performance of each drying unit, a methodology proposed by Leon et al. (2002) was used in this study. The instantaneous 
moisture content $\left(M_{t}\right)$ on dry basis at any time can be calculated from the following equation:

$$
M_{t}=\left[\left(M_{o}+1\right)^{W_{t}} / W_{o}\right]-1
$$

\section{Drying rate}

The drying rate was found by the decrease of the water concentration during the time interval between two subsequent measurements divided by this time interval. The drying rate (DR) was therefore expressed by the following equation.

$$
D R=M w / M d s . t
$$

Eqn 16

\section{Drying efficiency}

To evaluate drying performance of each solar drier overall system, the drying efficiency ( $\eta d)$ is used. The system efficiency of a solar drier is a measure of how effectively the input energy to the drying system is used in drying product. System efficiency for the forced convection solar driers needs to take into account the energy consumed by the fan. The following equation is then used:

$$
\eta_{d}=M_{W} \cdot \Delta H l_{\text {I.A.t }}+P f
$$

Eqn 17

\section{Pick-up efficiency}

Pick-up efficiency is useful for evaluating the actual evaporation of moisture from the product inside the drier. It is a direct measure of how efficiently the capacity of air to absorb moisture is used. The pick-up efficiency is defined as the ratio of the moisture picked up by the air in the drying chamber to the theoretical capacity of the air to absorb moisture. Mathematically it can be expressed by the following equation:

$$
\eta_{p}=\frac{\left(h_{o}-h_{i}\right)}{\left(h_{a s}-h_{i}\right)}=\frac{M_{w}}{\rho V_{t}\left(h_{a s}-h_{i}\right)}
$$

\section{IN-VITRO DIGESTIBILITY TECHNIQUE}

An in-vitro dry matter digestibility (IVDMD) on dried banana wastes (Tilley and Terry, 1963) method was adopted by (Abd El-Ghani et al., 
2002) to determine In-vitro Dry Matter Disappearance (IVDMD). According to the preliminary evaluation done in-vitro, banana wastes was evaluated metabolically by lambs.

\section{RESULTS AND DISCUSSION}

The energy and exergy analyses for banana agricultural (tree residues) and industrial (peels) wastes drying process via three different mixedmode forced convection type solar driers were performed with data obtained from the experiments. Figures $\mathbf{4}$ and $\mathbf{5}$ show the values of the incident solar radiation measured on a horizontal surface, the ambient air temperature, the temperature of the drying chamber, Trapezoidal solar collector and at fan outlet versus drying time. Note that t-8h (10:00AM) in the drying time axis corresponds to drier's load at morning of the second drying day. It can be seen that the solar radiation has its maximum value of 871.56 and $872.208 \mathrm{~W} / \mathrm{m}^{2}$ at $12: 00 \mathrm{PM}$ (drying time t$1 \mathrm{~h}$ and $\mathrm{t}-10 \mathrm{~h}$ ) for the first and second drying day respectively. Relative humidity has its maximum value of $62.45 \%$ at $6: 00 \mathrm{PM}$ and temperature of $29.75^{\circ} \mathrm{C}$ (drying time $\mathrm{t}-8 \mathrm{~h}$ ) and its minimum value of $36.9 \%$ at 1:00PM (t-3h) and temperature of $36.3^{\circ} \mathrm{C}$ at the first drying day. The same behavior is obtained at the second drying day as ambient air temperature increases to $34.05^{\circ} \mathrm{C}$ at $12: 00 \mathrm{PM}(\mathrm{t}-11 \mathrm{~h})$ its relative humidity decreases to $33.5 \%$ and as ambient air temperature decreases to $29.5^{\circ} \mathrm{C}$ at $6.00 \mathrm{PM}(\mathrm{t}-17 \mathrm{~h})$ its relative humidity increases to $55.9 \%$. Ambient air and Trapezoidal, Quonset and Cylindrical drying chamber temperatures increase with drying time until maximum values of 38.8 and $49.1^{\circ} \mathrm{C}, 55.2$ and $53.9^{\circ} \mathrm{C}$ are reached, respectively. It was observed that the drying air temperature inside greenhouse solar collector, drying chamber and at fan outlet depend on ambient air temperature, Figure 6. As ambient air temperature increases to $35.1^{\circ} \mathrm{C}$, the Trapezoidal, Quonset and Cylindrical solar collectors drying air temperatures increase to 43.7, 45.3 and $51.9^{\circ} \mathrm{C}$ respectively for the first drying day and to $44.1,48.7$ and $54.3^{\circ} \mathrm{C}$ respectively in the second drying day; their drying chamber temperature increases to $45.9,49.5$ and $52.8^{\circ} \mathrm{C}$ respectively in the first drying day and to $49.1,52.2$ and $53.4^{\circ} \mathrm{C}$ in the second drying day respectively; and temperature at fan outlet increases to 45.3, 48.7 and $48.7^{\circ} \mathrm{C}$ respectively and in the second drying day to $48.7,51.9$ and 
$51.9^{\circ} \mathrm{C}$ respectively. Cylindrical solar drier records the highest air drying temperatures under the same weather conditions. Other observation is, as ambient air temperature increases, the temperature of drying air inside greenhouse solar collectors and their drying chambers increase gradually until certain level. In other words, thermal capacity saturation is reached. The Figures of solar collectors and drying chambers of the three drier systems illustrate that the solar thermal capacity is achieved at ambient air temperature of $33^{\circ} \mathrm{C}$. Finally it can be stated that the thermal capacity range of the three solar collectors and their drying chambers is between 29 to $33^{\circ} \mathrm{C}$ but at fan outlet is different.
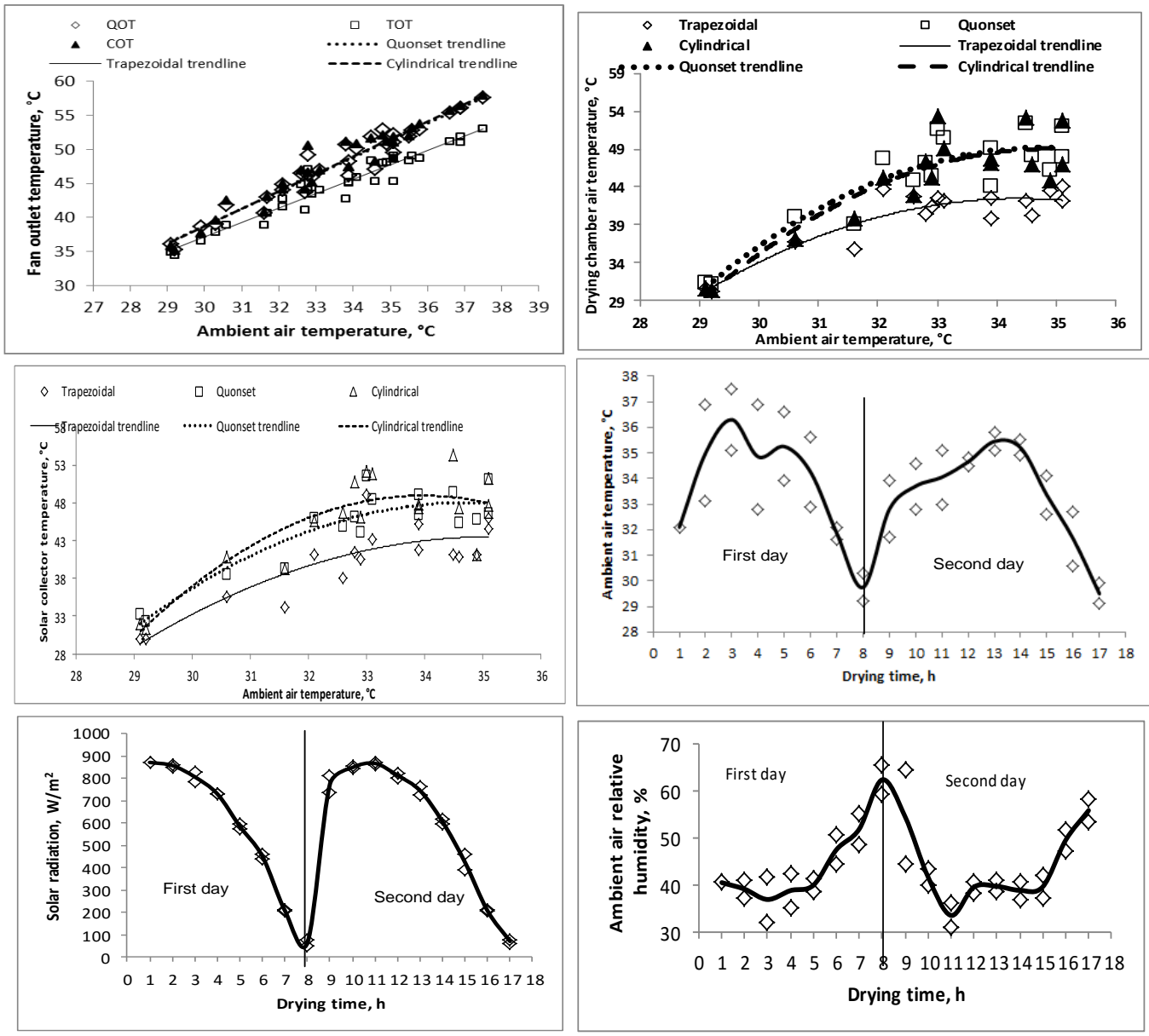

Figure 4: The effect of ambient air temperature on the temperature of the three solar driers and weather conditions variations with the drying time. 
This means the whole thermal system is still work under its thermal capacity for the three solar driers due to sun exposure time duration for drying air from greenhouse solar collector to greenhouse drying chamber above drying material trays and passing through it to get out by centrifugal fan. This journey time aids heat energy to transfer to drying air, so the whole solar system range is between 29 to $38^{\circ} \mathrm{C}$. From the results shown, it can be concluded that the solar collectors volume need to be doubled to meet with the ambient air temperature range, but the greenhouse drying chamber has the ability to compensate that. In future the drying air at fan outlet can be reused and exploit its energy in air heating.

Figure 5 shows drying air capacity based on absolute humidity difference and based on temperature difference variations of the collectors, drying chambers and at fan outlet for each solar drier related to drying hours. The highest drying air capacity values are obtained at daytime of 12:00 -3:00PM (t-2 to t-5h) in the first drying day and from 12:00 - 2:00PM (t-11 to t-13h) in the second drying day. The drying air capacity based on absolute humidity and on temperature difference are raised from $0.00004 \mathrm{~kg} \mathrm{H}_{2} \mathrm{O} / \mathrm{m}^{3}$ and $6.05^{\circ} \mathrm{C}$ of the ambient to 0.00795 and 17.6, 0.0043 and 16.34 and $0.00578 \mathrm{~kg} \mathrm{H}_{2} \mathrm{O} / \mathrm{m}^{3}$ and $16.8^{\circ} \mathrm{C}$ by Cylindrical, Quonset and Trapezoidal solar collectors respectively in the first drying day. The same behavior is achieved in the second drying day. The Cylindrical solar collector has the highest values of drying air capacity. Once the drying air enters the drying chamber; the drying air capacity decreases from 0.00795 to $0.005885 \mathrm{~kg} \mathrm{H}_{2} \mathrm{O} / \mathrm{m}^{3}$ and from 0.00578 to 0.004353 for Cylindrical and Trapezoidal solar driers, respectively. These losses are due to moisture migration from the drying product. But in the Quonset drier, the drying air capacity of $0.00429 \mathrm{~kg}$ $\mathrm{H}_{2} \mathrm{O} / \mathrm{m}^{3}$ is still raising inside drying chamber because the drying air doesn't reach stability at the moment of entering drying chamber (ranged from 0.0058 to $0.006 \mathrm{~kg} \mathrm{H}_{2} \mathrm{O} / \mathrm{m}^{3}$ according to its temperature). So there is some of lost in drying air capacity such as Cylindrical and Quonset solar driers, but on the other hand, the drying air is still need energy to achieve stability meeting the temperature inside drying chamber makes summation is increasing in drying air capacity from 0.004295 to 
$0.00578 \mathrm{~kg} \mathrm{H}_{2} \mathrm{O} / \mathrm{m}^{3}$. It is noticed that if drying chamber is not loaded, the drying air capacity will increase enough meeting the temperature raising inside drying chamber but the product nearly makes the drying air capacity at the same range especially for temperature difference. The relationship between drying air temperature inside each solar drier or collector and its drying capacity is illustrated in Figure 5. It is observed that, as drying air temperature increases from 35 to 42 , the drying air capacity based on absolute humidity increases from 0.0028 to 0.0049 , 0.001 to 0.0025 and 0.0018 to $0.0038 \mathrm{~kg} \mathrm{H}_{2} \mathrm{O} / \mathrm{m}^{3}$ for Trapezoidal, Quonset and Cylindrical solar collectors respectively. The Trapezoidal solar collector goes to be stable $0.005 \mathrm{~kg} \mathrm{H}_{2} \mathrm{O} / \mathrm{m}^{3}$ after drying air temperature $45^{\circ} \mathrm{C}$; and the two other solar collectors have the ability to increase according to their temperatures. The specific enthalpy in the Trapezoidal solar collector has higher fluctuations than that of the other two driers. In General, the specific enthalpy inside the solar collector has lower values than that of the ambient specific enthalpy in the first drying day and much varies in the second drying day, Figure 9. This may be attributed to that the specific enthalpy is analyzed to its origins latent specific enthalpy and sensible specific enthalpy for Trapezoidal solar collector. The results show that the ambient air has higher latent specific enthalpy than air inside Trapezoidal solar collector, but the sensible specific enthalpy of the air inside Trapezoidal solar collector has higher values than that of ambient air, Figure 6. This interprets that some latent enthalpy is transferred from the Trapezoidal solar collector to drying chamber by some fluid mechanics which controls the drying air movement during drying process. The maximum specific enthalpy added by Cylindrical solar collector is $14 \mathrm{~kJ} / \mathrm{kg}$ at $2: 00 \mathrm{PM}(\mathrm{t}-4 \mathrm{~h})$ in the first drying day and adds 26.02 and $22.36 \mathrm{~kJ} / \mathrm{kg}$ at $10: 00 \mathrm{AM}(\mathrm{t}-9 \mathrm{~h})$ and 1:00PM (t-12h), respectively and decreases gradually until reached to be nothing at 5:00PM $(\mathrm{t}-7 \mathrm{~h})$ in the first drying day and 5:00PM $(\mathrm{t}-14 \mathrm{~h})$ in the second drying day. Whereas, the maximum specific enthalpy added by the drying chamber in the first drying day at 1:00PM (t-3h) is $14.315 \mathrm{~kJ} / \mathrm{kg}$ and in the second day at $\mathrm{t}-9 \mathrm{~h}$ and $\mathrm{t}-14 \mathrm{~h}$ is 21.87 and $21.635 \mathrm{~kJ} / \mathrm{kg}$, respectively. The overall heat energy gained by the solar collector during the first drying day is $2351.97,4182.44,4313.99 \mathrm{~kJ}$ and 
in the second drying day is $2868.48,4932.16,4894.79 \mathrm{~kJ}$ for Trapezoidal, Quonset and Cylindrical solar driers respectively. While the drying chamber can collect $1738.82,931.37,1285.91 \mathrm{~kJ}$ during the first drying day and $1874.11,521.67,1055.52 \mathrm{~kJ}$ during the second drying day for Trapezoidal, Quonset and Cylindrical solar driers under drying process conditions. The Trapezoidal solar collector has the lowest heat energy collection while its drying chamber has the highest collection. Theoretically the three drying chambers should have the same heat energy collection because the three drying chambers have the same dimensions and shapes, but the drying chamber of Trapezoidal solar collector has the highest heat energy gained. So Therefore, this result proves the introduced interpretation of specific enthalpy of Trapezoidal solar collector which is lower than the ambient despite of the sensible specific enthalpy is vice versa. The difference is due to the latent specific enthalpy transferred to drying chamber and make its collected energy is the highest. The heat energy collected by greenhouse solar collector and drying chamber differs in case of the drier is loaded or not. While the drying chamber without load has the same behavior in energy collection like the solar collector but the amount is depending on the aperture area only. In the first drying day, the heat energy gained varied from 34.27 to $76.53 \mathrm{~J} / \mathrm{s}$ in at the time of $12: 00 \mathrm{PM}(\mathrm{t}-2 \mathrm{~h})$ to $6: 00 \mathrm{PM}(\mathrm{t}-8 \mathrm{~h})$ in the first drying day and from 14.2 to $75 \mathrm{~J} / \mathrm{s}$ in at the time of $2: 00 \mathrm{PM}(\mathrm{t}-13 \mathrm{~h})$ to 6:00PM (t-17h) in the second drying day. Thermal collection efficiency for each solar drier is ranged from 23.91 to $33.02,24.09$ to 30.78 and 16.16 to $20.33 \%$ at time from 11:00AM (t-1h) to 4:00PM (t-6h) for Cylindrical, Quonset and Trapezoidal solar driers respectively, Figure 6. The maximum thermal efficiency is 55.7, 60.19 and $32.87 \%$ obtained at 6:00PM (t-8h) for Cylindrical, Quonset and Trapezoidal solar driers respectively in the first drying day and the second day behaves the same. The thermal collection efficiency achieved by (Banout et al., 2011) ranges from 49 to $75 \%$ depending on the collector type and obstacles used in the collector. It is obvious that thermal collection efficiency increases drastically after $\mathrm{t}-6 \mathrm{~h}$ and $\mathrm{t}-14 \mathrm{~h}$ due to the lower solar energy and heat energy stored inside. Hence, thermal collection efficiencies at these times are exceptional case. The average thermal collection 
efficiency is 31.12, 29.96 and $19.44 \%$ for Cylindrical, Quonset and Trapezoidal solar driers. Cylindrical solar drier recorded the highest thermal collection efficiency. The energy utilization ratio (EUR) of the three utilized solar driers, at the first stage of drying process, is higher than those at drying times later due to the moisture tension force at initial is lower. During the drying process, the moisture content of the product decreases for the same energy input. Furthermore, at the beginning of the drying process, the energy efficiencies are observed to be higher than at the final stage and are found to be low at the end of drying process. The average energy utilization ratio for Cylindrical, Quonset and Trapezoidal solar driers is $48.77,52.06$ and $55.58 \%$ respectively. The average values of energy utilization ratio in the second drying day are higher than those of the first drying day due to latent specific enthalpy of drying air in the second drying day is higher than that of the first one. Trapezoidal solar drier shows the highest EUR of 55.58\% due to the accumulated latent specific enthalpy inside its drying chamber that escaped from Trapezoidal solar collector.

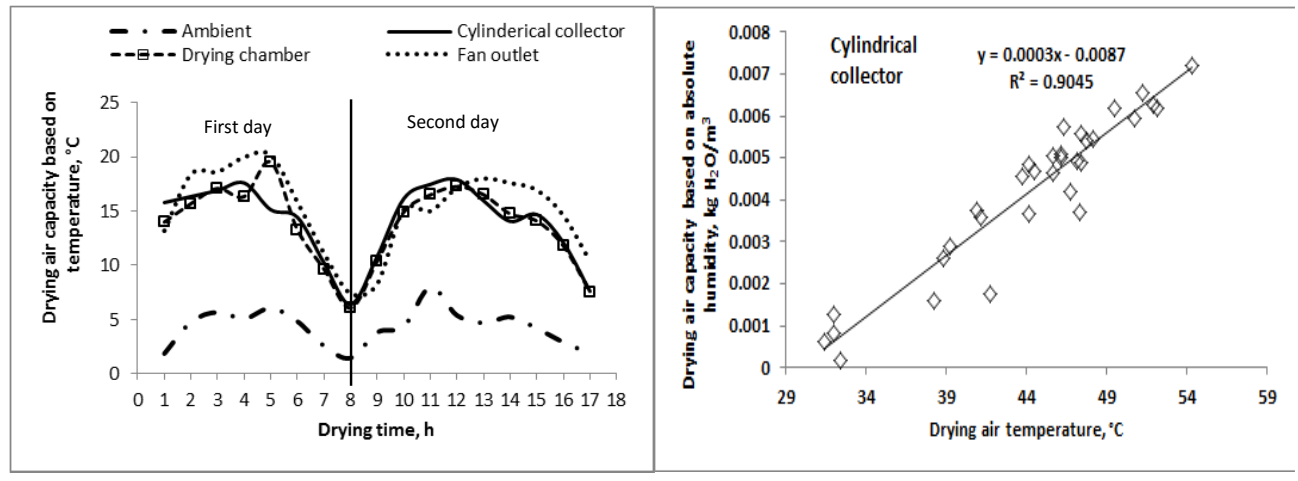

Figure 5: Drying air capacity at inlet conditions (ambient), collector, drying chamber and fan outlet based on absolute humidity and temperature differences.

A mixed-mode forced convection solar drier's types are different in exergy analysis about those indirect drier types because drying chambers are exposed directly to solar energy and sharing the exergy addition to drying air stream. Exergy summation is the exergy gained by greenhouse drying chamber minus exergy used for evaporation. As ambient air temperature increases the exergy losses increases. 


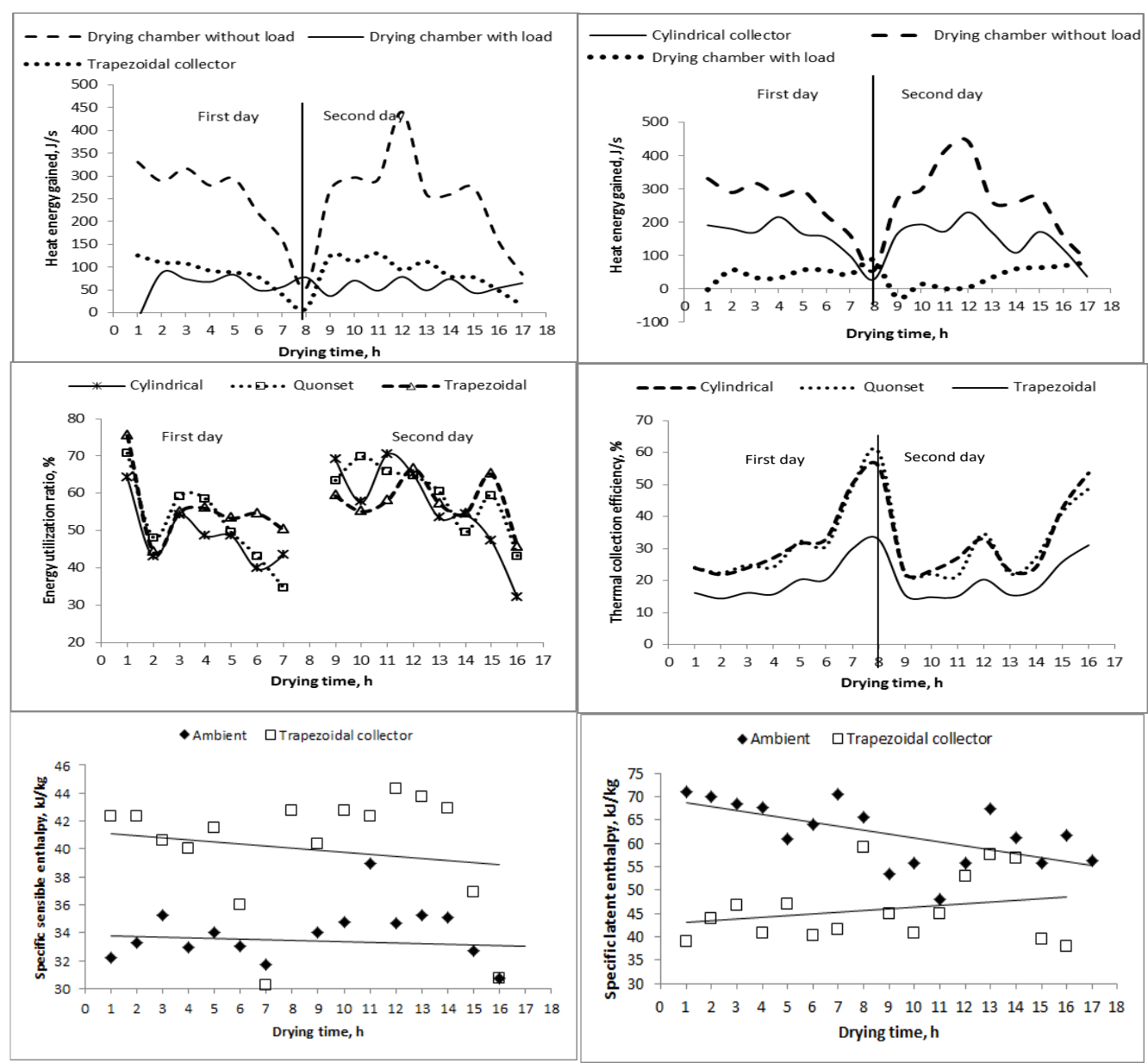

Figure 6: Energy analysis for the three solar driers as heat energy gained by the system, thermal collection efficiency and energy utilization ratio.

The energy and exergy analyses of the drying process of olive mill wastewater (OMW) using an indirect type natural convection solar drier were presented by (Celma and Cuadros, 2009) and it was found that the exergetic efficiencies of the drying chamber decreased as inlet temperature was increased, provided that exergy losses became more significant. So the drying process needs exergy of $0.3567,0.1423$ and $1.5 \mathrm{~kJ} / \mathrm{kg}$ drying air for Trapezoidal, Quonset and Cylindrical solar driers respectively during the first drying day, and needs 0.94186, 0.44184, $1.218 \mathrm{~kJ} / \mathrm{kg}$ drying air for Trapezoidal, Quonset and Cylindrical solar driers respectively during the second drying day from the exergy carried 
by drying air from their solar collectors. Generally these amounts of exergy are needed at the last three hours of drying time due to more exergy losses with lower moisture content. It is observed that, at the beginning of drying process, the moisture content profiles in both cases are nearly the same. As drying progresses, the moisture content decreases. The following discussion is concerned with studying the effect of chopping length and drying bed depth on moisture migration mechanism under the same conditions. In Figure 8, the observed moisture content profiles of chopping length $5 \mathrm{~cm}$ with bed depth $5 \mathrm{~cm}$ are higher than those of chopping length $3 \mathrm{~cm}$ with bed depth $5 \mathrm{~cm}$ and the same behavior for bed depth of $8 \mathrm{~cm}$ was found. The chopping length of $5 \mathrm{~cm}$ is higher than those of $3 \mathrm{~cm}$. In the case of bed depth, the moisture content profiles of bed depth $8 \mathrm{~cm}$ are higher than those of $5 \mathrm{~cm}$ for both chopping length $3 \mathrm{~cm}$ and $5 \mathrm{~cm}$. For banana peels, the moisture content profile of bed depth $5 \mathrm{~cm}$ is higher than that of bed depth $3 \mathrm{~cm}$. From the comparison above between moisture content profiles, it can be concluded that lower bed depth and lower chopping length lead to lower moisture content due to lower chopping length has higher specific surface area faced drying air stream and bed depth too has lower drying air resistance that let permit the drying air passed and penetrate the drying product easily. The lowest final moisture content based on dry basis obtained by Trapezoidal, Quonset and Cylindrical solar driers are 1.7 (0.66), 1.2 (0.61) and 0.9 (0.56) $\mathrm{kg} \mathrm{H}_{2} \mathrm{O} / \mathrm{kg}$ dry matter ( $\mathrm{kg} \mathrm{H}_{2} \mathrm{O} / \mathrm{kg}$ wet matter) respectively at bed depth $5 \mathrm{~cm}$ and chopping length $3 \mathrm{~cm}$ for Quonset and Cylindrical solar driers, but at for Trapezoidal solar drier, the lowest value obtained at bed depth $8 \mathrm{~cm}$ and the same chopping length of $3 \mathrm{~cm}$. The Cylindrical solar drier has the lowest final moisture content if compared to the other two driers. It is observed from Figure 9 that, there are two different drying curve profiles; the drying rate curve profile at the first drying day is higher than the drying rate curve at the second drying day until the equilibrium moisture content is reached and the other drying rate curve profile is the drying rate at the first drying day is lower than the drying rate curve at the second drying day until the equilibrium moisture content is reached obtained. The difference in these curves is due to drying airflow resistance above the drying trays. In other words, if 
the drying air can penetrate easily the product, the drying rate at the first drying day is higher than at the second one which corresponds to higher initial moisture content of the product at the beginning of drying process. On the other hand if the drying air has higher resistance or can't getting through easily, the drying rate is lower until the size of product is reduced in the second drying day (by picking up some moisture from the product in the first drying day) aiding the drying air to pass fluently and then drying rate becomes higher. The highest drying rate occurred in case of Cylindrical solar drier $0.0302 \mathrm{~kg} \mathrm{H}_{2} \mathrm{O} / \mathrm{kg}$ dry matter.min where the final moisture content $0.9 \mathrm{~kg} \mathrm{H} \mathrm{H}_{2} \mathrm{O} / \mathrm{kg}$ dry matter is reached after $17 \mathrm{~h}$ of drying followed by Quonset solar drier with drying rate $0.02116 \mathrm{~kg} / \mathrm{kg}$ dry matter.min and final moisture content $1.24 \mathrm{~kg} \mathrm{H}_{2} \mathrm{O} / \mathrm{kg}$ dry matter after $17 \mathrm{~h}$ and Trapezoidal solar drier with drying rate $0.018462 \mathrm{~kg}$ $\mathrm{H}_{2} \mathrm{O} / \mathrm{kg}$ dry matter.min and final moisture content $2.83 \mathrm{~kg} \mathrm{H}_{2} \mathrm{O} / \mathrm{kg}$ dry matter after $17 \mathrm{~h}$ of drying time. The highest drying rate achieved for each treatment of experiment was of 0.0302, 0.016981, 0.02003 and $0.01473 \mathrm{~kg} \mathrm{H} \mathrm{H}_{2} \mathrm{O} / \mathrm{kg}$ dry matter.min for D5T3, D5T5, D8T3 and D8T5 respectively. These results correspond to observations reported by Hossain and Bala (2007) in the study focused on solar drying of red chilli. In all the previous studies of drying process the relationship between energy supply and drying rate was investigated. The drying rate supposed to be directly proportional to energy supply. But in this case under study there are other variables are controlling the drying rate inside the solar driers.

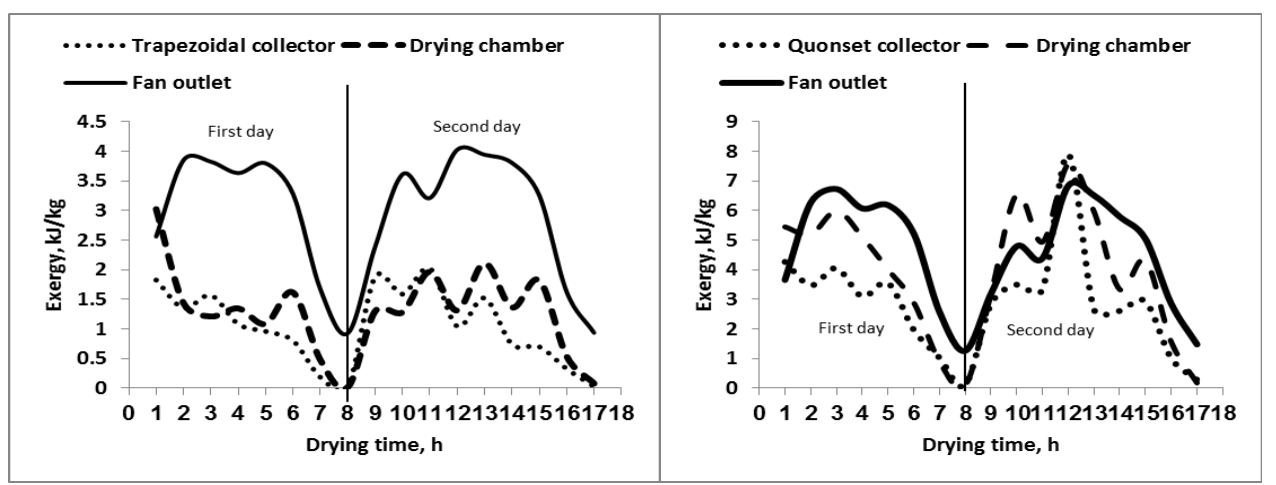

Figure 7: Exergy as a function of drying time inside solar collector, drying chamber and at fan outlet for each solar drier. 
The interested variables are specific enthalpy, drying air capacity, heat energy gained, exergy and moisture content. According to the multiple regression equations, it is obvious that the drying rate for each treatment is totally related to these variables and in general $\mathrm{P}$-value $<0.01$ for each variable. While other variables such as solar drier type, drying bed depth and chopping length are considered in the analysis, it is also affect significantly on the drying rate P-value $<0.01$, Table 4 . In the first drying day, the drying process starting at 11:00AM and tends to increase to from $\mathrm{t}-5 \mathrm{~h}$ (4:00PM), $\mathrm{t}-5 \mathrm{~h} \quad(4: 00 \mathrm{PM})$ and $\mathrm{t}-6 \mathrm{~h} \quad(5: 00 \mathrm{PM})$ for Trapezoidal, Quonset and Cylindrical solar drier respectively.

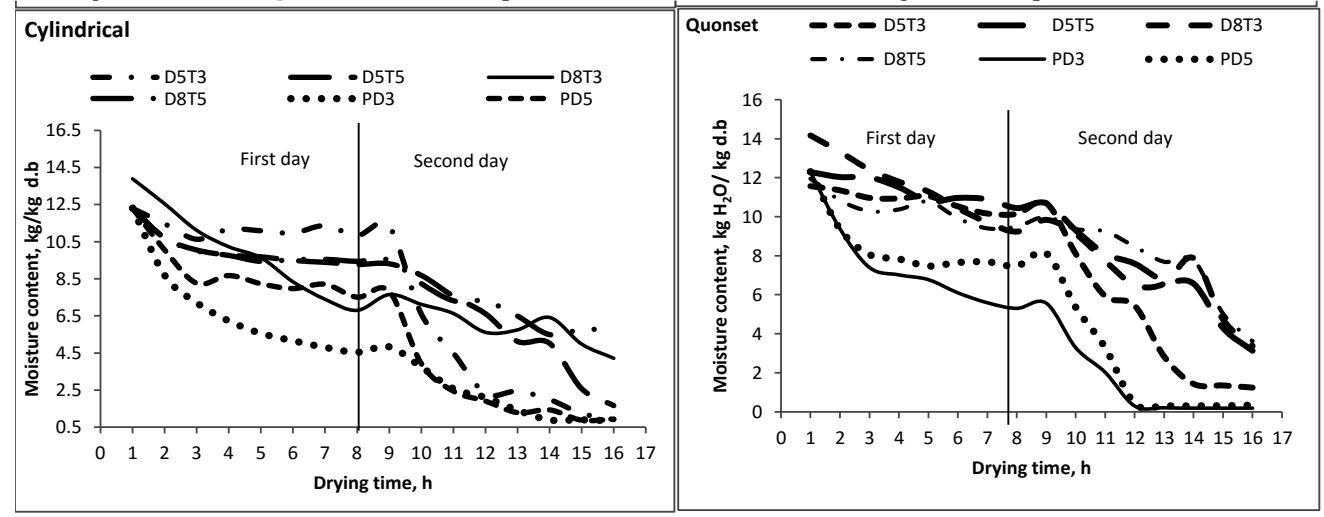

Figure 8: Moisture content on dry basis as a function of drying time.

The increment in drying efficiencies is due to the solar energy starts to be lower and the amount of heat energy stored in the drier and product is still used in evaporation, the evidence of that in the second drying day the drying efficiencies are starting lower with values of 0.3 to $0.9 \%$. This interprets that some solar energy is primarily used in product heating for further evaporation. The highest drying efficiencies obtained in the first drying day by Cylindrical solar drier are 12, 24.69, 38.23, 24.74, 60.2 and 37.43 for D5T3, D5T5, D8T3, D8T5, PD3 and PD5, respectively. In the second drying day, the drying efficiency remains nearly constant around values of 46.2, 17.9, 4.17, 15.1, 14.4 and 32.5\% for D5T3, D5T5, D8T3, D8T5, PD3 and PD5, respectively from $\mathrm{t}-10 \mathrm{~h}$ to $\mathrm{t}-15 \mathrm{~h}$ for Cylindrical solar drier. The drying efficiencies at the beginning and ending of drying process are exceptional cases. The highest drying 
efficiency is achieved at D5T3 of $46.2 \%$ by Cylindrical solar drier followed by Quonset solar drier $32.96 \%$ and finally by Trapezoidal solar drier $20.5 \%$.

Table 4: Drying rate multiple regression analysis.

\begin{tabular}{|c|c|c|c|c|c|c|c|}
\hline \multicolumn{4}{|c|}{ Banana tree wastes } & \multicolumn{4}{|c|}{ Banana peels } \\
\hline Variables & Coefficients & $\mathrm{p}$-value & $\mathrm{R}^{2}$ & Variables & Coefficients & p-value & $\mathrm{R}^{2}$ \\
\hline Intercept & 0.042366 & $\mathrm{P}<0.01$ & \multirow{9}{*}{0.732} & Intercept & -0.00985 & $\mathrm{P}<0.01$ & \multirow{9}{*}{0.710} \\
\hline Drier type & -0.00102 & $\mathrm{P}<0.01$ & & Drier type & -0.00052 & $\mathrm{P}<0.01$ & \\
\hline Drying bed depth & -0.00107 & $\mathrm{P}<0.01$ & & Drying bed depth & 0.001221 & $\mathrm{P}<0.01$ & \\
\hline Chopping length & $4.53 \mathrm{E}-05$ & $\mathrm{P}<0.01$ & & Specific enthalpy & 0.000658 & $\mathrm{P}<0.01$ & \\
\hline Specific enthalpy & 0.000418 & $\mathrm{P}<0.01$ & & Drying air capacity & 0.000992 & $\mathrm{P}<0.01$ & \\
\hline $\begin{array}{l}\text { drying air } \\
\text { capacity }\end{array}$ & 0.001253 & $\mathrm{P}<5.0$ & & Energy & $1.8 \mathrm{E}-05$ & $\mathrm{P}<0.01$ & \\
\hline Energy gained & $6.96 \mathrm{E}-06$ & $\mathrm{P}<0.01$ & & Exergy & 0.000384 & $\mathrm{P}<0.01$ & \\
\hline Exergy & -0.00027 & $\mathrm{P}<0.01$ & & M.C wb & -0.02978 & $\mathrm{P}<0.01$ & \\
\hline M.C wb & -0.08575 & $\mathrm{P}<0.01$ & & ----- & ------ & & \\
\hline
\end{tabular}

The initial pick-up efficiencies of the three solar driers show higher values in the first and second drying days is due to banana peels' moisture can be easily picked-up at the beginning of the first drying day, but banana tree wastes nearly has a determined pick-up efficiency for each treatment, while in the second drying day is due to the trapped moisture in product's void spaces. Pick-up efficiency ranged from 4.19 to $14 \%$, from 1.3 to $7.8 \%$ and from 1.3 to $10.7 \%$ for Trapezoidal, Quonset and Cylindrical solar driers respectively. Generally the product with chopping length $3 \mathrm{~cm}$ has the highest pick-up efficiency with both bed depths 5 and $8 \mathrm{~cm}$. Banana peels with bed depth 3 and $5 \mathrm{~cm}$ has the highest pick-up efficiencies with Trapezoidal solar drier of 13.37 and $14 \%$ respectively is due to smaller chopping length help the drying air to pick-up the moisture easily for its higher specific surface area. 


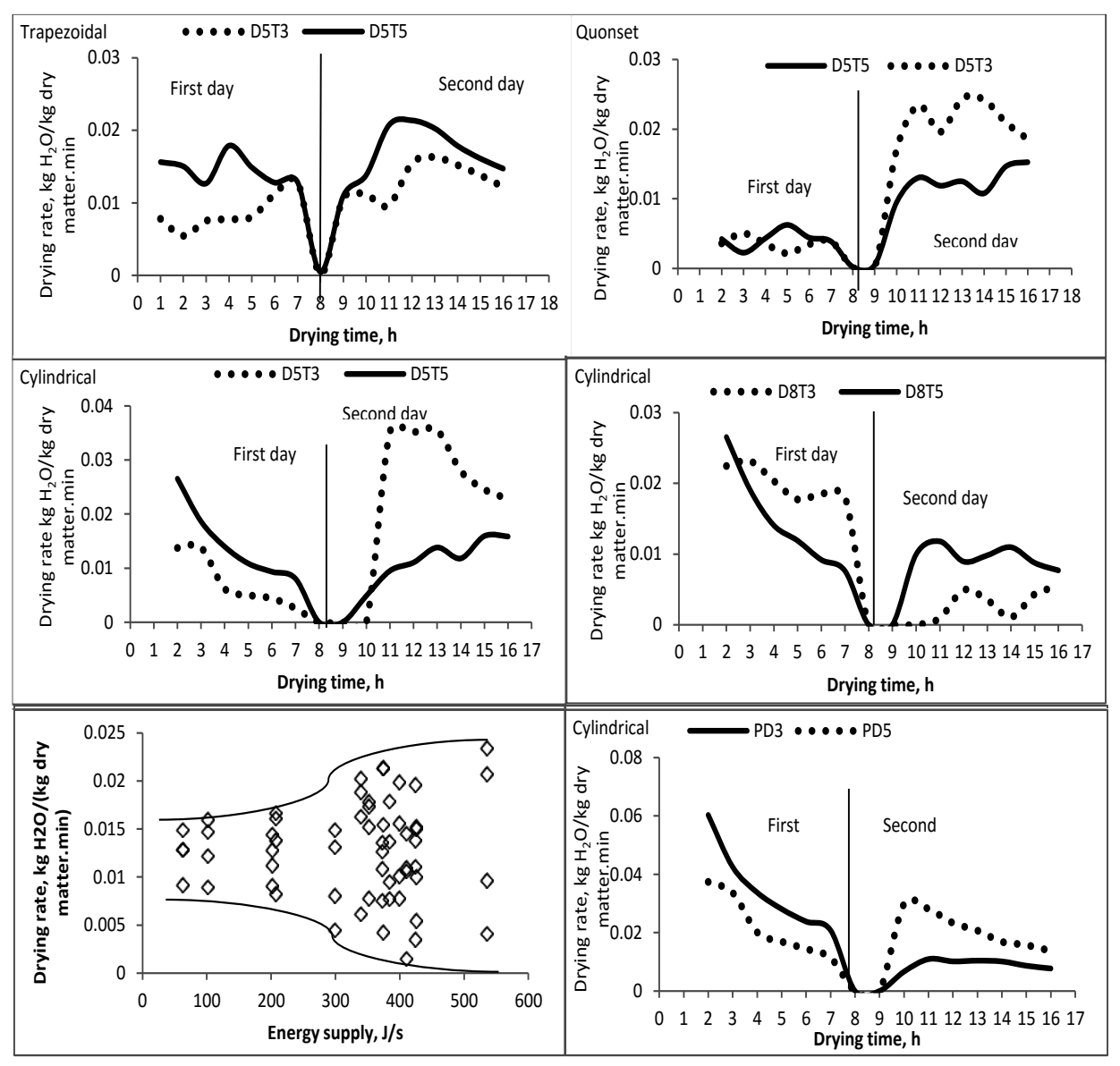

Figure 9: Drying rate as a function of drying time and energy supply for each solar drier under different treatments.

\section{Digestion coefficients, chemical composition and in vitro dry matter}

\section{digestibility}

Chemical composition of banana wastes is presented in Table 5. It's revealed that banana wastes have close digestibility values (IVDMD) of 70.1 to concentrate feed of 87.1. The digestion coefficients for all components in banana wastes are presented in Table 6 and compared with concentrate feed the feed intake as TDN of 45.7 is close to concentrate feed of 56.4 . 
Table 5: Chemical composition and In-vitro dry matter digestibility, \%.

\begin{tabular}{|l|l|l|l|l|l|l|l|l|}
\hline Item & $\begin{array}{l}\text { Dry } \\
\text { matter }\end{array}$ & $\begin{array}{l}\text { Organic } \\
\text { matter }\end{array}$ & $\begin{array}{l}\text { Crude } \\
\text { protein }\end{array}$ & $\begin{array}{l}\text { Either } \\
\text { extract }\end{array}$ & $\begin{array}{l}\text { Crude } \\
\text { fiber }\end{array}$ & $\begin{array}{l}\text { Nitrogen } \\
\text { free } \\
\text { extract }\end{array}$ & Ash & $\begin{array}{l}\text { In-vitro dry } \\
\text { matter } \\
\text { digestibility }\end{array}$ \\
\hline Banana wastes & 90.60 & 88.6 & 8.620 & 2.40 & 29.67 & 38.46 & 11.40 & 70.10 \\
\hline Concentrate feed & 90.5 & 89.1 & 16.4 & 3.2 & 13.66 & 46.34 & 10.9 & 87.1 \\
\hline
\end{tabular}

Table 6: Digestion coefficients and feeding value (\%) of the ingredients.

\begin{tabular}{|c|c|c|c|c|c|c|c|c|}
\hline \multirow{2}{*}{ Items } & \multirow{2}{*}{$\begin{array}{c}\text { Dry } \\
\text { matter }\end{array}$} & \multirow{2}{*}{$\begin{array}{l}\text { Organic } \\
\text { matter }\end{array}$} & \multirow{2}{*}{$\begin{array}{l}\text { Crude } \\
\text { protein }\end{array}$} & \multirow{2}{*}{$\begin{array}{l}\text { Either } \\
\text { extract }\end{array}$} & \multirow{2}{*}{$\begin{array}{l}\text { Crude } \\
\text { fiber }\end{array}$} & \multirow{2}{*}{$\begin{array}{c}\text { Nitrogen } \\
\text { free } \\
\text { extract }\end{array}$} & \multicolumn{2}{|c|}{ Nutritive value } \\
\hline & & & & & & & TDN & DCP \\
\hline Banana wastes & 50.13 & 52.07 & 57.13 & 45.57 & 40.56 & 58.07 & 45.7 & 4.95 \\
\hline Concentrate feed & 68.4 & 77.4 & 70.2 & 85.53 & 45.23 & 89.17 & 56.4 & 11.51 \\
\hline
\end{tabular}

\section{CONCLUSIONS}

Drying air and drier type were analyzed energetically to show their effectiveness on drying process evolution inside drying chambers. The drying air characteristics under interest are drying air capacity based on absolute humidity difference and on temperature difference and specific enthalpy (latent and sensible). Three greenhouse solar driers performance was evaluated by calculating the amount of heat energy gained by the solar system as a whole and by each component (collector and drying chamber), thermal collection efficiency and exergy available inside drying chamber. The drying process effectiveness under different methods of banana wastes distribution on the drying trays (D5T3, D5T5, D8T3, D8T5, PD3 and PD5) was illustrated as product moisture content wet basis and dry basis and drying rate. The indicators judging drying process inside three different greenhouse solar driers in relation to drying air characteristics are energy utilization ratio, drying efficiency and Pickup efficiency. Drying air capacity based on absolute humidity difference and on temperature difference, the difference is between adiabatic state and instantaneous state whether is for absolute humidity or temperature. Drying air capacity was measured at four locations (for ambient as initial conditions, solar collector, drying chamber and at fan outlet). The Cylindrical solar collector has the highest effect on drying air capacity that can increases drying air capacity rapidly, but the other two driers 
need some additional time to achieve the required level. While the Quonset solar drier is adding the highest amount of specific enthalpy if compared to the two others. Both Quonset and Cylindrical solar driers have nearly the same heat energy gained of 4932 and $4894.8 \mathrm{~kJ}$ in the second drying day. The same trend about thermal collection efficiency, both Quonset and Cylindrical solar driers have the highest efficiency of 28.46 and $27.44 \%$ respectively. Exergy analysis was used in this study to ensure that solar driers' volumes are suitable for meeting drying air requirements achieving minimum entropy generated. Exergy resultant inside drying chamber for each solar drier indicates that the driers have sufficient volumes meeting drying process guaranteeing the greenhouse drying chamber with forced drying need their solar collectors for drying process completeness at times from 10:00AM to 12:00PM in the first drying day and the drying chamber can work independently afterwards. The Cylindrical drying chamber needs the highest exergy of $1.5 \mathrm{~kJ} / \mathrm{kg}$ drying air from its collector in the second drying day especially at last three hours due to evaporation is progressive gradually obtaining the lowest final moisture content of $0.9 \mathrm{~kg} \mathrm{H} \mathrm{H}_{2} \mathrm{O} / \mathrm{kg}$ dry basis. It was observed for the Cylindrical solar drier, the moisture content decreases dramatically in the second drying day, ensuring the highest drying rate $0.0302 \mathrm{~kg} \mathrm{H}_{2} \mathrm{O}$ for D5T3. Drying rate is a resultant factor of specific enthalpy, drying air capacity, heat energy gained by solar collectors, exergy, waste distributions on drying trays and wastes moisture content. These variables have a significant effect on drying rate $\mathrm{p}<0.01$.

$$
\begin{gathered}
D R=0.042366-0.00102 D T-0.00107 \text { dep }+0.000045 \text { thic }+0.000418 S e \\
+0.001253 A C+0.000007 \text { Eng }-0.00027 \text { Exg }-0.08575 \mathrm{MC} \\
D R=-0.00985-0.00052 D T-0.001221 \mathrm{dep}+0.000658 \mathrm{Se}+0.000992 \mathrm{AC} \\
+0.000018 \mathrm{Eng}-0.000384 \mathrm{Exg}-0.02978 \mathrm{MC}
\end{gathered}
$$

Where $D T$ is drier type, dep is drying depth, Se is specific enthalpy, $A C$ drying air capacity, Eng is energy gained, Exg is exergy available and $M C$ is wastes moisture content. Energy utilization ratio for Cylindrical, Quonset and Trapezoidal solar driers is 48.77, 52.06 and 55.58\% respectively. Mean energy utilization ratio in the second drying day is higher than that of the first drying day due to latent specific enthalpy of 
drying air in the second drying day is higher than that of the first drying day. The drying efficiency for D5T3, D5T5, D8T3, D8T5, PD3 and PD5 is of $46.2,17.9,4.17,15.1,14.4$ and $32.5 \%$, respectively from $\mathrm{t}-10 \mathrm{~h}$ to $\mathrm{t}-$ 15h for Cylindrical solar drier. D5T3 and PD5 are the most suitable waste distribution on drying trays and the highest drying efficiency with all driers' type. The product with chopping length $3 \mathrm{~cm}$ has the highest pick-up efficiency with both bed depths 5 and $8 \mathrm{~cm}$ due to its highest specific surface area. Pick-up efficiency ranged from 4.19 to $14 \%$, from 1.3 to $7.8 \%$ and from 1.3 to $10.7 \%$ for Trapezoidal, Quonset and Cylindrical solar driers respectively.

\section{REFERENCES}

Abdallah, S. E. 2010. Thermal efficiency enhancement of a solar drier for hay making from sugar beet tops. AMA-Agricultural Mechanization in Asia Africa and Latin America, 41(4): 87-98.

Abd El-Gawad, A. M.; W. H. Abd El-Malik; S. M. Allam and I. M. ElSaid. 1994. Utilization of banana, tomato and potato by-products by sheep. Egyptian J. Anim. Prod.Vol. 31, supplement issue, Nov.: 215.

Abd El-Ghani, A. A.; E. I. Shehata; E. M. Ibrahim and F. M. R. El-Feel. 2002. Performance of lambs fed rations containing banana wastes. Egyptian J. Nutrition and Feeds, 5(2): 235-250.

Akpinar, E. K.; Y. Bicer and C. Yildiz. 2003. Thin layer drying of red pepper. Journal of Food Engineering, 59: 99-104.

Akpinar, E. K.; A. Midilli and Y. Bicer. 2006. The first and second law analyses of thermodynamic of pumpkin drying process. Journal of Food Engineering, 72:320-31.

Akpinar, E. K. 2005. Determination of suitable thin layer drying curve model for some vegetables and fruits. Journal of Food Engineering, 73: 75-84.

Amer, B. M. A.; M. A. Hossain and K. Gottschalk. 2010. Design and performance evaluation of a new hybrid solar drier for banana. Energy Conversion and Management, 51: 813-820.

ASAE. 1998. Moisture relationships of plan-based agricultural products. ASAE standard D245.5, AM. Soc. Agric. Eng. St. Joseph. MI.

Babalis, S. J. and V. G. Belessiotis. 2004. Influence of the drying conditions on the drying constants and moisture diffusivity during 
the thin-layer drying of figs. Journal of Food Engineering, 65: 44958.

Banout, J.; P. Ehl; J. Havlik; B. Lojka; Z. Polesny and V. Verner. 2011. Design and performance evaluation of a Double-pass solar drier for drying of red chilli (Capsicum annum L.). Solar Energy, 85: 506515.

Celma, A. R. and F. Cuadros. 2009. Energy and exergy analyses of OMW solar drying process. Renewable Energy, 34: 660-666.

Ceylan, I and A. Ergun. 2014. Psychrometric analysis of a timber drier. Case Studies. Thermal Engineering, 2: 29-35.

Dincer, I. and A. Z. Sahin. 2004. A new model for thermodynamic analysis of a drying process. International Journal of Heat and Mass Transfer, 47(4): 645-52.

Dincer, I. 2002. On energetic, exergetic and environmental aspects of drying systems. Int. J. Energy Res., 26:717-27.

Doymaz, I. 2004. Convective air drying characteristics of thin layer carrots. Journal of Food Engineering, 61:359-64.

Doymaz, I. 2005. Drying behavior of green beans. Journal of Food Engineering, 69: 161-5. a.

Doymaz, I. 2005. Drying characteristics and kinetics of okra. Journal of Food Engineering, 69: 275-9.b.

Doymaz, I. 2006. Thin layer drying behavior of mint leaves. Journal of Food Engineering, 74: 370-5.

Ekechukwu, O.V. and B. Norton. 1999. Review of solar energy drying systems II: an overview of solar drying technology. Energy Conversion and Management, 40: 615-655.

Ertekin, C. and O. Yaldiz. 2004. Drying of eggplant and selection of a suitable thin layer drying model. Journal of Food Engineering, 63: 349-59.

Hossain, M. A. and B. K. Bala. 2007. Drying of hot chilli using solar tunnel drier. Solar Energy, 81: 85-92.

Hossain, M. A.; J. L. Woods and B. K. Bala. 2005. Optimization of solar tunnel drier for drying of chilli without color loss. Renewable Energy, 30: 729-742.

Ibrahim, M. A.; F. Holmann; M. Hernandez; A. Camero. 2000. Contribution of Erythrina protein banks and rejected bananas for 
improving cattle production in the humid tropics. Agroforestry Systems, 49: 245.

Karim, M D. A. and M. N. A. Hawlader. 2005. Drying characteristics of banana: theoretical modeling and experimental validation. Journal of Food Engineering, 70: 35-45.

Koyuncu, T. 2006. Performance of various design of solar air heaters for crop drying applications. Renewable Energy, 31: 1073-1088.

Leon, M. A.; S. Kumar and S. C. Bhattacharya. 2002. A comprehensive procedure for performance evaluation of solar food driers. Renewable and Sustainable Energy Reviews, 6: 367-393.

Marie-Magdeleine, C.; M. Boval; L. Philibert; A. Borde and H. Archimède. 2010. Effect of banana foliage (Musa x paradisiaca) on nutrition, parasite infection and growth of lambs, Livestock Science, 131: 234-239.

Midilli, A and H. Kukuk. 2003. Energy and exergy analyses of solar drying process of pistachio. Energy, 28: 539-56a.

Midilli, A. and H. Kucuk. 2003. Mathematical modeling of thin layer drying of pistachio by using solar energy. Energy Conversion and Management, 44:11-22b.

Ministry of Agriculture 2013. Economics Bull. Central Dept. of Agric., Cairo, Egypt.

Mohapatra, D.; S. Mishra and N. Sutar. 2010. Banana and its by-product utilisation: an overview. Journal of Scientific \& Industrial Research, 69: 323-329.

Panchariya, P. C.; D. Popovic and AL. Sharma 2002. Thin layer modeling of black tea drying process. Journal of Food Engineering; 52: $349-57$.

Sabarez, H. T. and W. E. Price. 1999. A diffusion model for prune dehydration. Journal of Food Engineering, 42: 167-72.

Simal S.; A. Mulet; J. Tarrazo and C. Rossello. 1996. Drying models for green peas. Food Chemistry, 55: 121-8.

Simate, I. N. 2003. Optimization of mixed-mode and indirect-mode natural convection solar driers. Renewable Energy, 28: 435-453.

Singh, S.; P. P. Singh and S.S. Dhaliwal. 2004. Multi-shelf portable solar drier. Renewable Energy, 29: 753-765.

Tilley, J. M. H. and R. Terry. 1963. A two-stage technique for the Invitro digestion forage crops, J. Brit Grass. Soc., 18:104. 
Tsatsaronis, G. 2007. Definitions and nomenclature in exergy analysis and exergoeconomics. Energy, 32:249-53.

Psychrometrics.2013.http://www.daytonashrae.org/psychrometrics_si.ht $\mathrm{ml}$.

Zhiqiang, Y. 2005. Development of solar thermal systems in China. Solar Energy Materials and Solar Cells, 86: 427-442.

الملخص العربيى

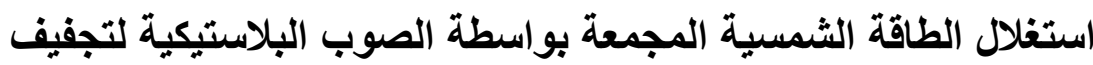 المخلفات الزراعية والصناعية بولية للموز الصنيو}

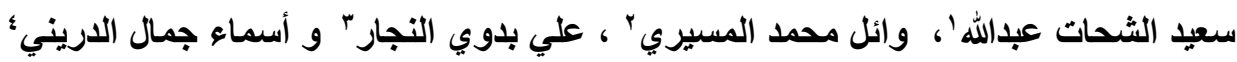

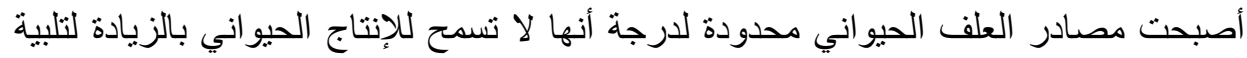

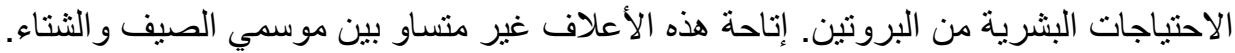

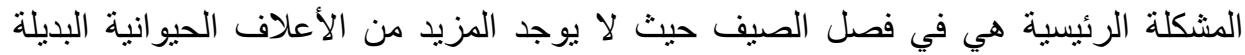

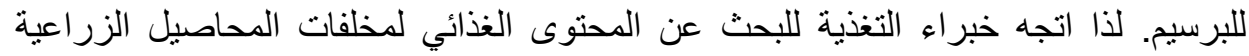

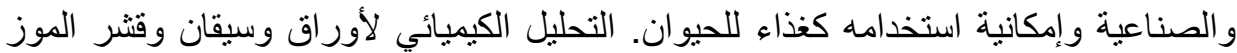

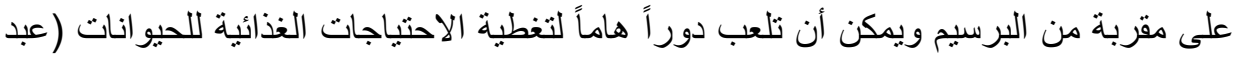

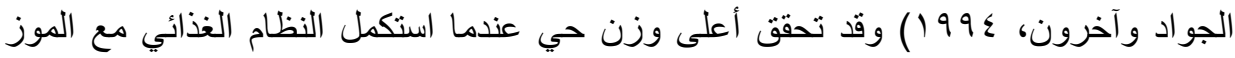

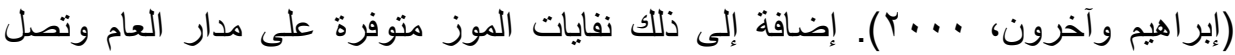

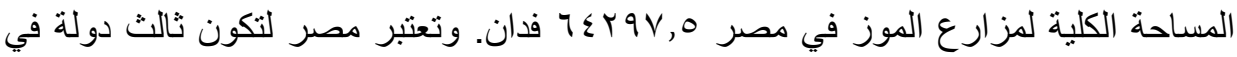

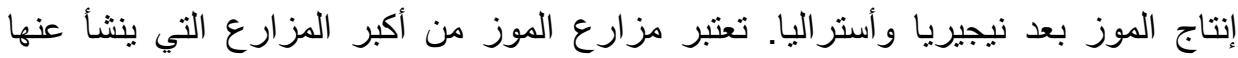

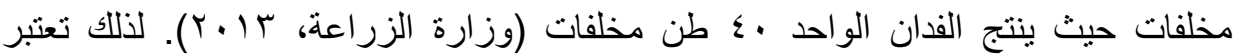

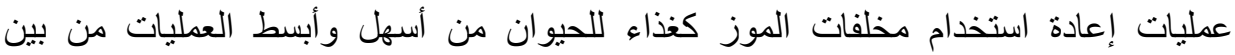

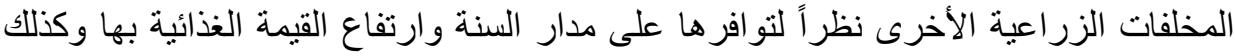

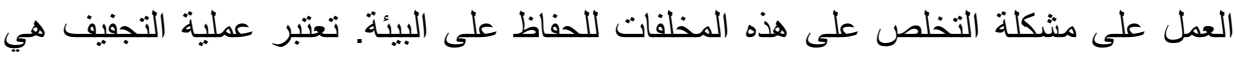

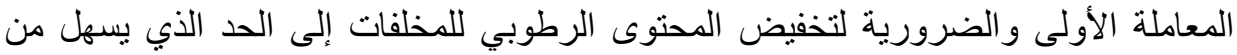

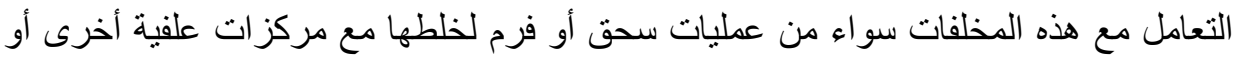

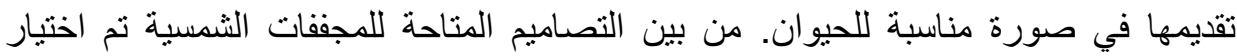

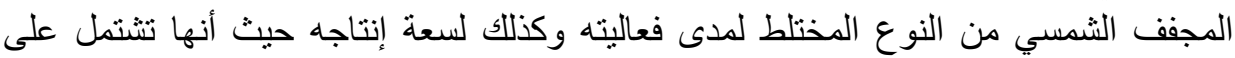

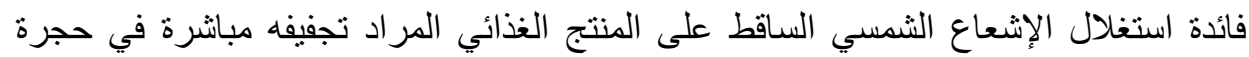

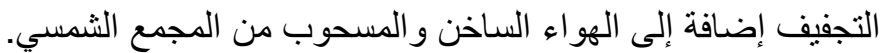

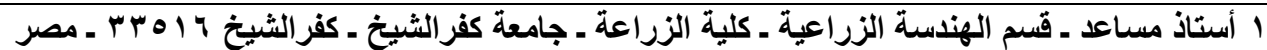

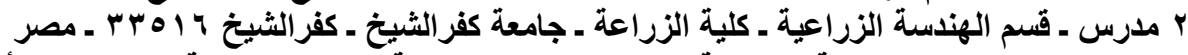

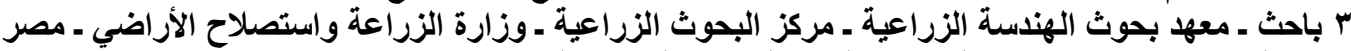

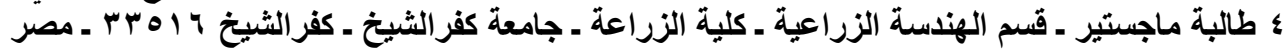


ثلاث أشكال هندسية مختلفة من المجمعات الثمسية ذات حيز فر اغي واحد هبV, ، متر مكعب

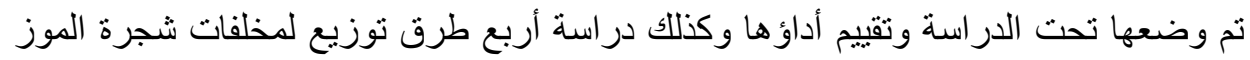

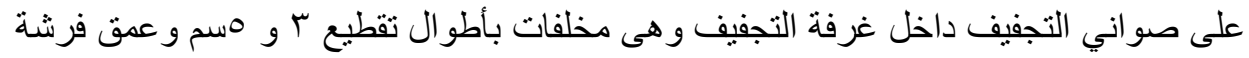
ه و رسم ولقشر الموز عمق فرشة ب و هسم. تم دراسة فعالية عملية التجفيف وكذلك أداء المجففات الثمسية الثلاثة بالتركيز على الطاقة الحرارية المكتسبة و المفقودة الشغالة

(Exergy)

خو اص هو اء التجفيف تحت الدر اسة هي كالآتي:

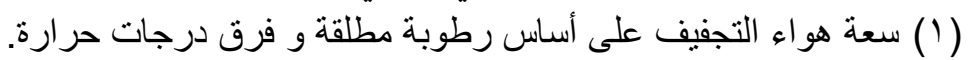

(Y) الإنثالبيا النو عية الكامنة و المحسوسة.

تم تقييم أداء الثناث مجففات الثمسية بحساب الثبة

(1) (1) كمية الطاقة الحرارية المجمعة بواسطة المجمع وكذللك غرفة التجفيف.

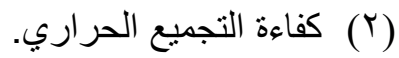

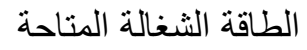

تم تقييم أداء عملية التجفيف لجميع صواني التجفيف ذات طرق توزيع فرشة مختلفة

$$
\text { المحتوى الرطوبي على أساس رطب و على أساس جاف. }
$$

معدل التجفيف.

المؤشر ات اللاتي تحكم أداء عملية التجفيف منسوبة إلى خو اص هو اء التجفيف.

(1) نسبة استخدام الطاقة.

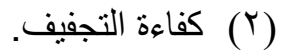

كفاءة نزع الرطوبة من المخلفات.

سعة هواء التجفيف (الفرق بين الرطوبة المطلقة أو درجة الحرارة الحالية والرة الرطوبة

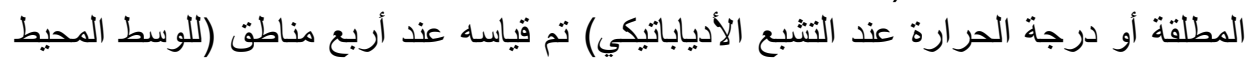

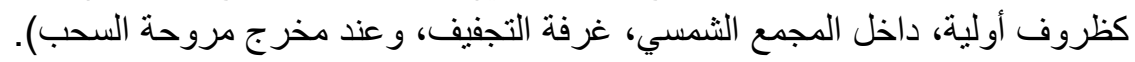

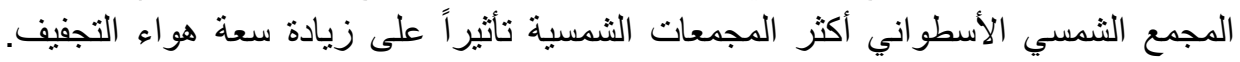

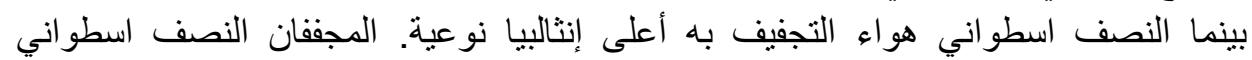

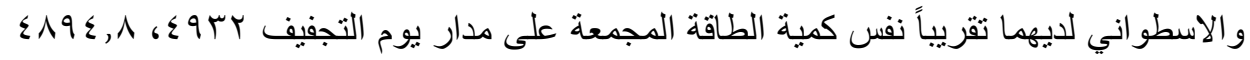

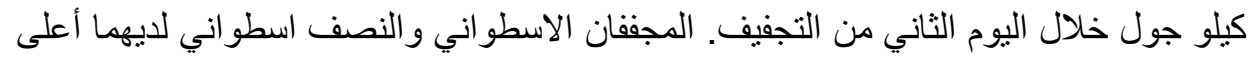

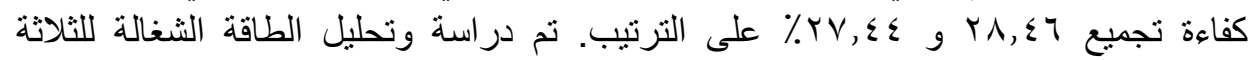

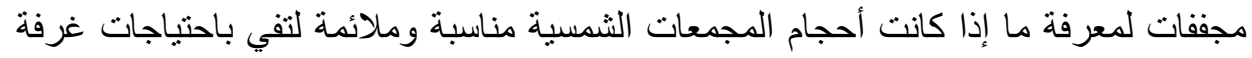

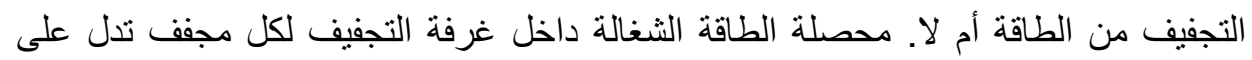
مدى ملائمة المجمع الثمسي. المجفف الاسطو اني يحتاج إلى أعلى كمية طاقة شغالة ه ه 1 كيلو

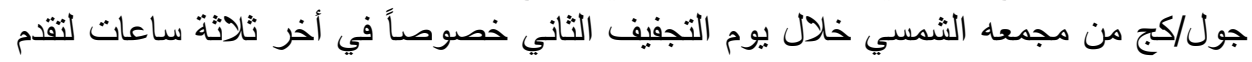

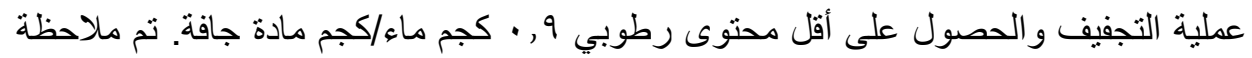

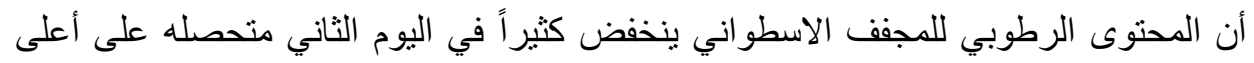


معدل تجفيف ץ • ץ • , • كجم ماء/دقيقة لعمق فرشة ه سم وطول قطع ب سم. معدل التجفيف ما هو إلا محصلة لـ الإنثالبيا النوعية، سعة هواء التجفيف، كمية الحرارة المكتسبة، الطاقة

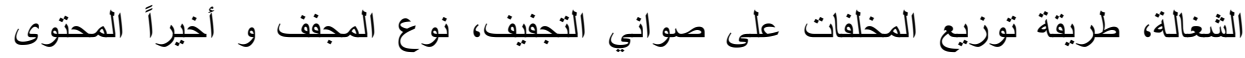

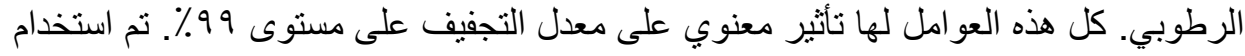
التحليل الإحصائي المتعدد الانحدار فتم الحصول على على المعادلات الآتية معبرة على معلى معدل التجفيف لمخلفات شجرة الموز وكذللك لقشر ثمار الموز $D R=0.042366-0.00102 D T-0.00107$ dep +0.000045 thic +0.000418 Se $+0.001253 \mathrm{AC}+0.000007 \mathrm{Eng}-0.00027 \mathrm{Exg}-0.08575 \mathrm{MC}$ $\mathrm{R}^{2}=0.732$ $D R=-0.00985-0.00052 D T-0.001221 d e p+0.000658 S e+0.000992 A C$ +0.000018 Eng $-0.000384 E x g-0.02978 M C$

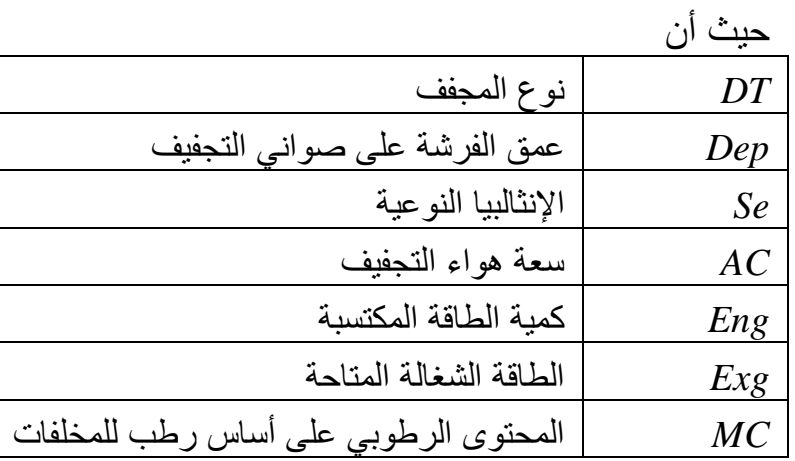

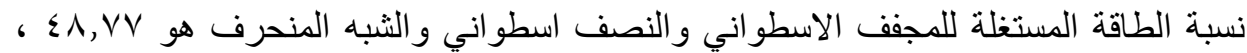

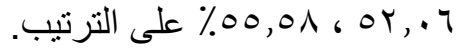
متوسط نسب الطاقة المستغلة في يوم التجفيف الثاني يكون أكبر منه عن اليوم الأول نتيجة إلى ألى أن الإنثالبيا النو عية لهو اء التجفيف في اليوم الثاني أعلى من اليوم الأول.

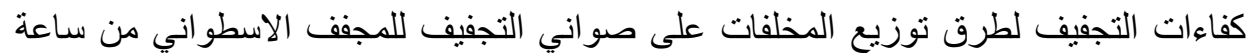
تجفيف • 1 ـ10 ساعة موضحة في الجدول الآتي:

\begin{tabular}{|c|c|}
\hline$\% \varepsilon \neg, Y$ & طول قطع المخلفات ب سم مع عمق فرشة هسم \\
\hline$\% 1 \vee, 9$ & طول قطع المخلفات ه سم مع عمق فرشة هسم \\
\hline$\% \varepsilon, 1 V$ & طول قطع المخلفات ب سم مع عمق فرشة ^سم \\
\hline$\% 10,1$ & طول قطع المخلفات ه سم مع عمق فرشة دسم \\
\hline$\% 1 \leq, \leq$ & عمق فرشة ساسم لقشر الموز \\
\hline$\% r, 0$ & عمق فرشة هسم لقشر الموز \\
\hline
\end{tabular}

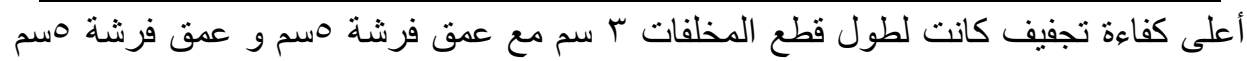

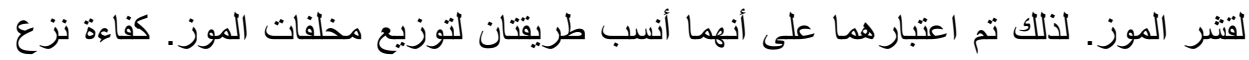

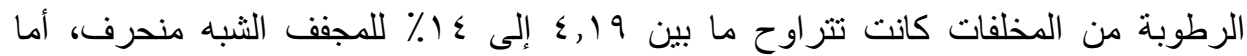

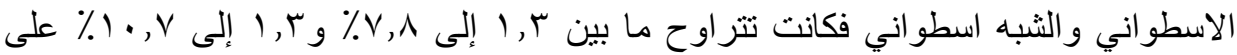
الترثيب. 